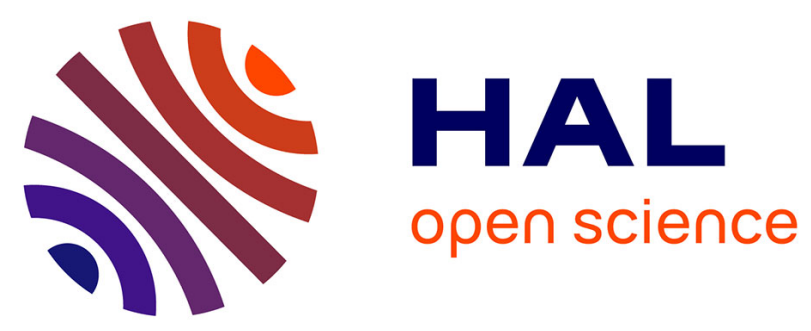

\title{
Resurrection of Indian Ocean humbug damselfish, Dascyllus abudafur (Forsskål) from synonymy with its Pacific Ocean sibling, Dascyllus aruanus (L.)
}

Philippe Borsa, Andrianus Sembiring, Cécile Fauvelot, Wei-Jen Chen

\section{- To cite this version:}

Philippe Borsa, Andrianus Sembiring, Cécile Fauvelot, Wei-Jen Chen. Resurrection of Indian Ocean humbug damselfish, Dascyllus abudafur (Forsskål) from synonymy with its Pacific Ocean sibling, Dascyllus aruanus (L.). Comptes Rendus Biologies, 2014, 337, pp.709-716. 10.1016/j.crvi.2014.09.001 . ird-01144018

\author{
HAL Id: ird-01144018 \\ https://hal.ird.fr/ird-01144018
}

Submitted on 20 Apr 2015

HAL is a multi-disciplinary open access archive for the deposit and dissemination of scientific research documents, whether they are published or not. The documents may come from teaching and research institutions in France or abroad, or from public or private research centers.
L'archive ouverte pluridisciplinaire HAL, est destinée au dépôt et à la diffusion de documents scientifiques de niveau recherche, publiés ou non, émanant des établissements d'enseignement et de recherche français ou étrangers, des laboratoires publics ou privés. 
To be cited as: P. Borsa, A. Sembiring, C. Fauvelot, W.-J. Chen, Resurrection of Indian-Ocean humbug damselfish, Dascyllus abudafur (Forsskål) from synonymy with its Pacific-Ocean sibling, Dascyllus aruanus (L.), Comptes Rendus Biologies 337 (2014) 709-716.

\section{Resurrection of Indian-Ocean humbug damselfish, Dascyllus abudafur (Forsskål) from synonymy with its Pacific-Ocean sibling, Dascyllus aruanus (L.)}

Résurrection de la demoiselle domino de l'océan Indien, Dascyllus abudafur (Forsskål), de la synonymie avec son espèce-jumelle de l'océan Pacifique, Dascyllus aruanus (L.)

Philippe Borsa a,*, Andrianus Sembiring b, Cécile Fauvelot a, Wei-Jen Chen c

a Institut de recherche pour le développement (IRD)-UR 227 and LabEx Corail, Nouméa, New Caledonia

b Indonesian Biodiversity Research Center (IBRC), Denpasar, Indonesia

c Institute of Oceanography, National Taiwan University, Taipei, Taiwan

* Corresponding author, present address : IRD UR 227 c/o Indonesian Biodiversity Research Center, Universitas Udayana, Jl Sesetan Gang Markisa 6, Denpasar, Indonesia. Tel. +62 812 37453473; e-mail : philippe.borsa@ird.fr 


\section{A B S T R A C T}

Previous phylogeographic studies of the humbug damselfish, a widespread Indo-West Pacific coral-reef fish, have revealed a split of two main mitochondrial lineages distributed on either side of the Indo-Pacific barrier. This has been interpreted as the result of vicariance. It has been hypothesized that reproductive barriers might currently limit gene flow between humbug damselfish populations from the Indian Ocean and the Pacific Ocean. In this study, we review the published phylogeographic information to update the distribution of the two main mitochondrial lineages of humbug damselfish. The Indian lineage was distributed from the Red Sea to the eastern extremity of the Sunda Shelf while the Pacific lineage, which diverged from the former by $0.6 \%$ net nucleotide divergence and diagnostic substitutions at three nucleotide sites at the cytochrome- $b$ locus, was distributed east and north of the Sunda Shelf. The two forms, which are also genetically distinct at nuclear loci, were also characterized by distinct pigmentation patterns. We argue that the two forms represent geminate species. Epithet aruanus Linnaeus is maintained for the Pacific-Ocean humbug damselfish while epithet abudafur (Forsskål) is here resurrected for the Indian-Ocean humbug damselfish. Future studies should focus on the population genetic structure of the transition zone between Dascyllus abudafur and D. aruanus.

Keywords: taxonomy; phylogeography; cryptic species; coral reef; Indo-West Pacific 


\section{R É S U M É}

Des études phylogéographiques antérieures sur la demoiselle domino, un poisson récifal à large distribution indo-ouest pacifique, ont montré une partition majeure entre lignées mitochondriales de part et d'autre de la barrière indo-pacifique. Ceci a été interprété comme étant le résultat d'un processus de vicariance. L'hypothèse que des barrières reproductives puissent présentement limiter le flux génique entre populations de la demoiselle domino de l'océan Indien et de l'océan Pacifique a été évoquée. Dans cet article, nous passons en revue les données publiées à ce jour, pour déterminer le plus précisément possible la distribution des deux grandes lignées mitochondriales chez la demoiselle domino. Nous montrons que la lignée mitochondriale indienne est présente de la mer Rouge au plateau continental de la Sonde alors que la lignée pacifique, qui est séparée de la première par $0.6 \%$ de divergence nucléotidique nette et par des substitutions diagnostiques à trois sites nucléotidiques au locus du cytochrome $b$, est présente à l'est et au nord du plateau de la Sonde. Les deux formes se distinguent également par leurs génotypes nucléaires, ainsi que par leurs patterns de pigmentation. Nous montrons ici que les deux formes représentent des espèces jumelles. L'épithète aruanus Linné est maintenue pour la demoiselle domino de l'océan Pacifique, tandis que l'épithète abudafur (Forsskål) est ressuscitée pour la demoiselle domino de l'océan Indien. Les études à venir devront aborder la structure génétique de la zone de transition entre Dascyllus abudafur et D. aruanus.

Mots-clés : taxonomie ; phylogéographie ; espèce cryptique ; récif corallien ; indo-ouest pacifique 


\section{Introduction}

A proportion of Indo-Pacific reef fish species exhibit some phylogeographic discontinuity coinciding with the Indo-Pacific barrier ([1,2] and references therein). It has been hypothesized that a majority of these phylogeographically structured species actually consist of pairs of geminate species, each restricted to a single ocean [3]. This hypothesis, if confirmed, would considerably affect our current understanding of what determines species richness in the Coral Triangle [4]. This would imply shifting the current paradigm of the Coral Triangle as biodiversity epicenter [4] towards the hypothesis that the higher species richness in the Coral Triangle artefactually results, at least in part, from the overlap in the geographic distributions of Indian and Pacific species [2, 3, 5].

Under the current taxonomic standards, evidence of morphological differentiation is required to support the recognition of separate species. As noted by J.E. Randall [6] about species differentiation between the Indian and the Pacific Oceans: "Many examples of such specific pairs are known [...] but perhaps there are others that may have diverged ecologically, behaviourly, or physiologically, but not enough morphologically for us to readily detect". Molecular population genetics should be considered in the latter, as it offers the tools and concepts to address the problem of cryptic species [7]. Actually, new species discoveries in fishes increasingly stem from molecular genetic studies (e.g. [8-14]).

Here, we examine the taxonomic status of a widespread Indo-West Pacific reef fish, the humbug damselfish, Dascyllus aruanus. The humbug damselfish is common in shallow reef habitats throughout the Indo-West Pacific. It has been used as a model-species for a number of ecological, behavioural, and population genetic studies [15-26]. The phylogeographic structure of the humbug damselfish indicates two main metapopulations across the Indo-West Pacific, each one specific to an ocean [26]. No mitochondrial haplotype characteristic of Indian-Ocean individuals has been found in the western Pacific and no Pacific haplotype has been found in the Indian Ocean $[25,26]$. The phylogeographic break as determined from mitochondrial haplotypes is located at the eastern edge of the Sunda Shelf [25]. Nuclear markers (microsatellites) have also been used for a similar distribution-wide analysis of geographic structure in humbug damselfish [26], showing a same distinct genetic break between the Indian and Pacific Oceans that could not be explained by mere isolation by distance [26]. These observations have been interpreted as the result of vicariance on either side of the Indo-Pacific barrier [26]. It has been hypothesized that reproductive barriers currently limit gene flow between humbug damselfish populations from the Indian Ocean and the Pacific Ocean [25].

We review the phylogeographic information available on the humbug damselfish and provide the geographical delineation of the two main mitochondrial lineages previously uncovered in this species [3, 2527]. The combined evidence from both mitochondrial DNA and nuclear DNA, and pigmentation patterns allows us to address the issue of cryptic speciation in the humbug damselfish. 


\section{Materials and Methods}

\subsection{Review of published sequence data}

Previous studies have produced the mitochondrial sequences of humbug damselfish from a total of 43 sampling sites throughout the Indo-West Pacific [3, 20, 25-27] (Fig. 1A). The published mitochondrial data selected for the present survey thus included the complete ATP6/8 gene sequences [842 base pairs (bp)] of 18 individuals from 10 sampling sites in the Indo-West Pacific [27], the partial cytochrome-oxidase I gene sequences (842 bp) of 11 individuals from two sampling sites in the southwestern Indian Ocean and one sampling site in the central Pacific [3], the partial control-region sequences (approximately 359 bp) of 401 individuals from 18 sampling sites in the Coral Triangle [25], and the partial cytochrome- $b$ gene sequences (1058 bp) of 260 individuals from 13 sampling sites throughout the Indo-West Pacific [26] (Supplementary material, Table S1). In each of the foregoing surveys, haplotypes have been determined as belonging to either one of two haplogroups, here coined 'Indian' and 'Pacific'. The humbug damselfish population of Cebu Strait, Philippines was sampled by both J.M. Raynal et al. [25] and S.-Y.V. Liu et al. [26]. The haplotype composition of the Cebu sample in [26] was therefore used to establish haplogroup relationships of the control-region haplotypes produced by [25]. The partial control-region sequence from an individual from Glorieuses Islands, southwestern Indian Ocean (C. Fauvelot, unpublished) clustered with haplotypes of the Central Java Sea, thus establishing that the latter belonged to the 'Indian' mitochondrial type (mitotype) [25]. In addition, we examined the set of partial control-region sequences ( $387 \mathrm{bp}$ ) of 45 individuals from 5 sampling sites in French Polynesia [20]. These sequences, accessible from GENBANK (http://www.ncbi.nlm.nih.gov/; accession nos. KM406787-KM406831) were included in a single FASTA file together with reference control-region sequences of the Indian and Pacific mitotypes, and the whole matrix was subjected to Neighbor-Joining analysis using the MEGA 5 package [28].

Similarly, multi-locus microsatellite genotypes from 13 samples from sites across the Indo-West Pacific (Fig. 1B) were determined to belong to either an 'Indian' or a 'Pacific' form according to their probability score under Bayesian structure analysis [26].

\subsection{Additional sampling and sequencing}

The cytochrome $b$ gene sequences of an additional sample of 6 individuals from Madang, Bismarck Sea were produced according to the methods and protocols detailed in [26]. Another 5 individuals from Serangan, on Bali Island, western shore of Lombok Strait were also sequenced at the cytochrome $b$ locus, using primers HIMBO1 (5'- G T G A C T T G A A A A A C C A C C G T T G -3') and HIMB02 (5'- A A T A G G A A G 
T A T C A T T C G G G T T T G A T -3'). Polymerase chain reaction was done in $25 \mu \mathrm{L}$ volumes, using 1 $\mu \mathrm{L}$ of template DNA, $4 \mu \mathrm{L}$ 10x PCR buffer (Applied Biosystems, Foster City CA, U.S.A.), $2.5 \mu \mathrm{L} 10 \mathrm{mM}$ dNTPs, $1.25 \mu \mathrm{L}$ of each primer at $10 \mathrm{mM}, 2 \mu \mathrm{L} 25 \mathrm{mM} \mathrm{MgCl} 2$ solution, $0.125 \mu \mathrm{L}$ AmplyTaq Gold ${ }^{\text {TM }}$ (Applied Biosystems) in doubly-distilled $\mathrm{H} 2 \mathrm{O}$. The thermocycling profile included an initial denaturation of $94{ }^{\circ} \mathrm{C}$ for $15 \mathrm{~s}, 38$ cycles of $94{ }^{\circ} \mathrm{C}$ for $30 \mathrm{~s}, 50^{\circ} \mathrm{C}$ for $30 \mathrm{~s}$, and $72{ }^{\circ} \mathrm{C}$ for $45 \mathrm{~s}$, with a final extension of $72{ }^{\circ} \mathrm{C}$ for $5 \mathrm{~min}$. All $11 \mathrm{new}$ sequences were then determined to haplogroup. For this, we compared them to previously published cytochrome $b$ gene sequences [26] by checking their nucleotide composition at diagnostic nucleotide sites under MEGA 5 [28]. Control-region sequences of another batch composed by 1 individual from Zanzibar, 3 individuals from the Mozambique channel, 5 from the Philippines, 1 from Guam, and 2 from Fiji, produced according to the protocols exposed in [20], and using primers $C R-A-D A\left(5^{\prime}-\mathrm{A}\right.$ T G A A T C T T A C A A C T C A A C A C C T G-3') and CR-E-DA (5'-T C A A C C A A G T A C A A C C C C T G T-3') specifically designed by one of us (CF) for D. aruanus were added, and similarly determined to one of the two main haplogroups.

\subsection{Pigmentation patterns}

Specimens from throughout the distribution of the species were photographed either live underwater or after being captured. The photographs were subsequently examined for pigmentation patterns. Additional photographs were retrieved from FishBase (http://www.fishbase.org/; [29]), and from the Barcoding of Life database (BOLD) (http://www.barcodinglife.com/). The sampling sites for individuals sampled for pigmentation patterns are reported in Fig. 1C. We focused on the intensity of the pigmentation of the blackish blotch at the basis of caudal fin as this was found to be variable among individuals. Four patterns were determined, from blackish (Fig. 2A; scored 3) to lacking pigmentation (Fig. 2B; scored 0) with two intermediate patterns, where the basis of caudal fin appeared light grey (scored 1) or solid grey (scored 2). The samples examined for pigmentation patterns were from the Red Sea ( $N=6$ individuals), the Mozambique Channel $(N=24)$, the Mascarene Islands $(N=6)$, the Maldives $(N=10)$, Bali $(N=8)$, Lombok $(N=18)$, Komodo $(N=8)$, the South China Sea $(N=5)$, the Philippines $(N=11)$, Raja Ampat $(N=35)$, the Bismarck Sea $(N=4)$, Chuuk $(N=1)$, Yap $(N=1)$, Lord Howe $(N=1)$, New Caledonia $(N=32)$, Fiji $(N=$ 4), and the Society Islands ( $N=1)$ (details in Supplementary material, Table S2 and Figs. S1-S7).

Mitochondrial sequences were available for $55 \%$ of the Indian-Ocean individuals and $41 \%$ of the PacificOcean individuals examined from photographs. "Indian Ocean" here refers to the region of the Indo-Pacific west of Lombok Strait, while "Pacific Ocean" refers to the region north and east of Lombok Strait.

\subsection{Statistical analyses}


The Mantel test implemented in GENETIX 4.02 [30] was used to test the correlation between pairwise $\theta$ estimates at the 7 microsatellite loci scored by [26] and their homologues at the cytochrome $b$ locus [26]. Net nucleotide distance between the Indian and Pacific mitochondrial haplogroups, based on Kimura-2 parameter nucleotide substitution model, was estimated under MEGA 5 [28]. A $\chi^{2}$ test of homogeneity was used to test the null hypothesis of no morphological difference between Indian and Pacific forms, as defined by, respectively, geography and mitotype.

\section{Results}

The frequencies of Indian and Pacific mitochondrial haplogroups per sampling site are given in Supplementary material, Table S1 and reported on Fig. 1A. New cytochrome- $b$ and control-region sequences are presented in Fig. 3 and in Supplementary material, Tables S3-S5. The new cytochrome- $b$ gene sequences from Lombok Strait $(N=5)$ comprised one sequence clustering with the previously identified Indian haplogroup, the remainder being of the previously identified Pacific haplogroup. Those from the Madang sample $(N=6)$ were all found to belong to the Pacific haplogroup. The control-region haplotypes sampled in Zanzibar and Glorieuses Islands all belonged to the Indian-Ocean haplogroup whereas all control-region haplotypes from the Philippines, Guam, Fiji, and French Polynesia belonged to the Pacific-Ocean haplogroup, as confirmed by Neighbor-Joining analysis. The nucleotide distance between the Indian and Pacific mitochondrial haplogroups, estimated from cytochrome $b$ gene sequences, was $0.6 \%$ (MEGA 5; Kimura-2 parameter net distance [28]).

Two main nuclear forms, Indian and Pacific, were also determined from microsatellite genotypes [26]. The distribution of these two forms is presented Fig. 1B. Genetic differences at nuclear loci were highly correlated with those at the mitochondrial locus (Appendix A).

The average score of pigmentation intensity was $2.51 \pm 0.68$ in the Indian-Ocean sample $(N=49)$ and $0.08 \pm 0.27$ in the Pacific-Ocean sample $(N=103)$. It was $2.61 \pm 0.63$ in the Indian mitochondrial form $(N=$ $28)$ and $0.20 \pm 0.40$ in the Pacific mitochondrial form $(N=46)$. The null hypothesis of no differences in pigmentation patterns between the two oceans was rejected ( $x^{2}$ test; $3 \mathrm{df} ; P<10^{-28}$ ), and so was it between the two mitochondrial forms ( $x^{2}$ test; $\left.3 \mathrm{df} ; P<10^{-13}\right)$. A majority $(62 \%)$ of individuals from the Indian Ocean exhibited a blackish blotch at the basis of the caudal fin and no-one was unpigmented. Conversely, a majority (92\%) of Pacific-Ocean individuals had an unpigmented caudal fin, the remainder (8\%) being slightly pigmented (details in Supplementary material, Table S2). All individuals of the Indian mitotype and for which a photograph was available, except two, possessed a blackish or solid-grey blotch at the basis of the caudal fin. For the two exceptions, from Europa Island, the basis of the caudal fin was light-grey. Conversely, the caudal fin of individuals of the Pacific mitotype was entirely white in most cases, or with a light-grey basis. Individuals sampled in the presumed zone of transition, i.e., Lombok Strait $(N=23)$ exhibited a variety of 
pigmentation patterns, from white to blackish (Supplementary material, Table S2). A specimen exhibiting the typical pigmentation pattern of the Indian-Ocean form is presented Fig. 2A, while a typical specimen of the Pacific form is presented Fig. 2B.

\section{Discussion}

Under K. de Queiroz's unified species concept [31] species are defined simply as separately evolving metapopulation lineages. K. de Queiroz [31] and other authors [32, 33] have emphasized the fundamental distinction between the definition of species, and species delimitation. The latter concerns properties of species, which include, e.g. morphological distinction, niche separation, reproductive isolation, and monophyly. These properties, one by one or altogether, constitute the lines of evidence researchers in practice may have access to, to hypothesize the existence of a species [31-33].

Several of the expected properties of species characterize the Indian Ocean versus the Pacific Ocean forms of humbug damselfish. The mitochondria of humbug damselfish from the Indian Ocean belong to a single lineage sister to that from the Pacific Ocean: the two forms are reciprocally monophyletic [25-27]. No location with mitotype (Indian vs. Pacific) polymorphism was observed, except at the western shore of Lombok Strait. The transition zone between the two mitochondrial forms lies east of the Central Java Sea and west of Lombok. A phylogeographic partition into two forms was also evident from allelic frequencies at nuclear loci, similar to that at the mitochondrial locus [26]. The location of the nuclear transition zone, which could not be determined with as much precision as the mitochondrial one, lied east of Madagascar and west of the central part of the Coral Triangle. The fact that population genetic differences at nuclear loci were highly correlated with differences at the mitochondrial locus indicates a common history of divergence, between the two forms, for the nuclear and mitochondrial genomes. The distribution of these two genetically separate forms of the humbug damselfish thus appears to be either parapatric, or slightly overlapping, in a narrow transition zone located at the western edge of the Coral Triangle. The two forms were also characterized by distinct pigmentation patterns, a criterion of considerable importance to taxonomists working on reef fishes (e.g., $[6,9,13])$. The two forms thus fulfill the criteria of morphological and genetic distinctness, which in turn allows us to consider them as distinct evolutionary units, hence separate species under the unified species concept [31]. In addition, their apparently parapatric distribution suggests some degree of reproductive isolation [34], which is another property of separate species [31].

In C. Niebuhr's posthume publication of the notes taken by P. Forsskål during his naturalist expedition to the Red Sea, a fish from Jeddah locally named abu dafur was mentioned in the following terms: "Chaetodon abu dafur Arab. est charactere Aruani Linn. Albus, fasciis tribus nigris: spinis Dors. 12. A. 2. Djidda habitat, rarior, inter corallia. Spith. Longit." [35]. It is possible that P. Forsskål considered this fish to be identical with C. Linnaeus' Chaetodon aruanus [36]. Dascyllus abudafur (Forsskål) was subsequently synonymized with D. aruanus (Linnaeus) 
$[37,38]$. Epithet aruanus has since then been maintained as the single valid one to designate both the Indian and the Pacific forms of the humbug damselfish [29, 39-42]. C. Linnaeus writes that D. aruanus "Habitat in Indiis" [43]. W.N. Eschmeyer precisely indicates the type-locality to be Aru Islands, Moluccas [42]. Since the Aru Islands are located within the distribution range of the Pacific mitotype, epithet aruanus is here kept to designate the Pacific form of the humbug damselfish. No description of the Indian-Ocean form of humbug damselfish is known before P. Forsskål's [42]. Hence, the Indian-Ocean form should be renamed D. abudafur.

There are numerous examples of allopatric lineage diversification among marine populations on either side of the Coral Triangle ([1, 2] and references therein). However, ecological factors that have led to lineage diversification, and those that maintain it, are difficult to identify because of the usual difficulty to distinguish contemporary, extrinsic barriers to larval connectivity, from internal barriers to gene flow, i.e. reproductive isolation [44, 45]. Transition zones are privileged situations for addressing such questions, for they offer the possibility to explore the apportion of the various mechanisms, passive vs. active, involved in speciation in marine organisms [46-48]. Investigating the population genetic structure of humbug damselfish populations across the transition zone between D. abudafur and D. aruanus is thus warranted. Phylogeographic surveys similar to those undertaken in $D$. aruanus ([25, 26]; present study) are needed to assess the taxonomic status of separate genetic forms within a nominal species, in all other cases where a geographic break has been identified.

\section{Taxonomy}

Dascyllus abudafur (Forsskål 1775), resurrected species

\subsection{Previous denominations}

Chaetodon abu dafur [35]; Pomacentrus aruanus [37]; Dascyllus aruanus ([38, 39, 49, 50]; other references in [42]).

\subsection{Diagnosis}

A Dascyllus of white pigmentation with three transversal black bands [35]. Caudal fin bilobate. Possesses a grey to blackish blotch at the basis of caudal fin that distinguishes it from its Pacific-Ocean sister-species, Dascyllus aruanus [43], whose tail is generally entirely white. Also distinct from $D$. aruanus by its cytochrome $b$ gene sequence: nucleotide sites nos. 450, 459 and 702 of the gene are diagnostic between the two species (Fig. 3). At these three sites, D. abudafur has the triplet (A, T, T) whereas D. aruanus has (G, C, C). 


\subsection{Distribution}

Indian Ocean, from the Red Sea to the Sunda Shelf.

\section{Disclosure of interest}

We have no conflicts of interest concerning this article.

\section{Acknowledgements}

We are grateful to G. Bernardi, J.-D. Durand, Husni, G. Mou-Tham and S. Planes for participating in the collection of samples; J. Bertrand for help with sequencing analysis; and an anonymous reviewer for helpful suggestions. Access to $18^{\text {th }}$ and $19^{\text {th }}$-century books was through the Biodiversity Heritage Library website (http://www.biodiversitylibrary.org). Sampling in the Mozambique Channel was done under Program CNRS-INEE/TAAF "Iles Eparses” (PHYLIP project: PB). Sampling in Dongsha was sponsored by the Oceanography Institute of NTU (WJC). Sampling in West Papua was done during LIPI/EKSPEDISI WIDYA NUSANTARA on board RV Baruna Jaya VIII in November-December 2007 (PB). Sampling at Madang was part of the NIUGINI 2012 biodiversity expedition (WJC). Sampling in New Caledonia was during the RESICOD workshop sponsored by the Fondation de recherche pour la biodiversité (M. Kulbicki, R. Myers, P. Pruvost and PB). WJC acknowledges grant support from Ministry of Science and Technology in Taiwan (MOST 101-2611-M-002 -016 -MY3). Also funded in part by IRD-UR 227 and IBRC. Designed the study: PB. Contributed reagents and/or materials and/or analysis tools: PB, AS, CF, WJC. Analyzed and interpreted the data: PB, WJC. Wrote the paper: PB.

\section{References}

[1] C. Fauvelot, P. Borsa, Patterns of genetic isolation in narrow-barred Spanish mackerel (Scomberomorus commerson) across the Indo-West Pacific, Biol. J. Linn. Soc. 104 (2011) 886-902.

[2] M.R. Gaither, L.A. Rocha, Origins of species richness in the Indo-Malay-Philippine biodiversity hotspot: evidence for the centre of overlap hypothesis. J. Biogeogr. 40 (2013) 1638-1648.

[3] N. Hubert, C. P.Meyer, H.J. Bruggemann, F. Guérin, R.J. L. Komeno, B. Espiau, R. Causse, J.T. Williams, S. Planes, Cryptic diversity in Indo-Pacific coral-reef fishes revealed by DNA-barcoding provides new support to the Centre-of-Overlap hypothesis, PloS One 7 (2012) e28987. 
[4] L. Pellissier, F. Leprieur, V. Parravicini, P.F. Cowman, M. Kulbicki, G. Litsios, S.M. Olsen, M.S. Wisz, D.R. Bellwood, D.Mouillot, Quaternary coral reef refugia preserved fish diversity, Science 344 (2014) 1016-1019.

[5] D.J. Woodland, Zoogeography of the Siganidae (Pisces): an interpretation of distribution and richness patterns, Bull. Mar. Sci. 33 (1983) 713-717.

[6] J.E. Randall, Zoogeography of coral reef fishes of the Indo-Pacific region, in: B. Séret, J.-Y. Sire (Eds.) Proc. $5^{\text {th }}$ Indo-Pacific Fish Conf. Nouméa 1997, Soc. Fr. Ichtyol., Paris, 1999, pp. 23-26.

[7] N. Knowlton, Molecular genetic analyses of species boundaries in the sea, Hydrobiologia 420 (2000) 7390.

[8] C.C. Baldwin, C.I. Castillo, L.A. Weigt, B.C. Victor, Seven new species within western Atlantic Starksia atlantica, S. lepicoelia, and S. sluiteri (Teleostei, Labrisomidae), with comments on congruence of DNA barcodes and species, ZooKeys 79 (2011) 21-72.

[9] P. Borsa, P. Béarez, W.-J. Chen, Gymnocranius oblongus (Teleostei: Lethrinidae), a new large-eye bream species from New Caledonia, C. R. Biol. 333 (2010) 241-247.

[10] P. Borsa, P. Béarez, S. Paijo, W.-J. Chen, Gymnocranius superciliosus and Gymnocranius satoi, two new largeeye breams (Sparoidea: Lethrinidae) from the Coral Sea and adjacent regions, C. R. Biol. 336 (2013) 233240.

[11] P. Borsa, A. Collet, L. Carassou, D. Ponton, W.-J. Chen, Multiple nuclear and mitochondrial genotyping identifies emperors and large-eye breams (Teleostei: Lethrinidae) from New Caledonia and reveals new large-eye bream species, Biochem. Syst. Ecol. 38 (2010) 370-389.

[12] P. Borsa, J.-D. Durand, K.-N. Shen, I.S. Arlyza, D.D. Solihin, P. Berrebi, Himantura tutul sp. nov. (Myliobatoidei: Dasyatidae), a new ocellated whipray from the tropical Indo-West Pacific, described from its cytochrome-oxidase I gene sequence, C. R. Biol. 336 (2013) 82-92.

[13] M. Puckridge, N. Andreakis, S.A. Appleyard, R.D. Ward, Cryptic diversity in flathead fishes (Scorpaeniformes: Platycephalidae) across the Indo-West Pacific uncovered by DNA barcoding, Mol. Ecol. Resour. 13 (2013) 32-42.

[14] D.J. Woodland, R.C. Anderson, Description of a new species of rabbitfish (Perciformes: Siganidae) from southern India, Sri Lanka and the Maldives, Zootaxa 3811 (2014) 129-136.

[15] P.F. Sale, Apparent effect of prior experience on habitat preference exhibited by the reef fish, Dascyllus aruanus (Pisces, Pomacentridae), Anim. Behav. 19 (1971) 251-256.

[16] P.F. Sale, Extremely limited home range in a coral reef fish, Dascyllus aruanus (Pisces, Pomacentridae), Copeia 1971 (1971) 324-327.

[17] P.F. Sale, Influence of corals in the dispersion of the pomacentrid fish, Dascyllus aruanus, Ecology 53 (1972) 741-744. 
[18] H.P.A. Sweatman, Field evidence that settling coral reef fish larvae detect resident fishes using dissolved chemical cues, J. Exp. Mar. Biol. Ecol. 124 (1988) 163-174.

[19] S. Planes, F. Bonhomme, R. Galzin, Genetic structure of Dascyllus aruanus populations in French Polynesia, Mar. Biol. 117 (1993) 665-674.

[20] C. Fauvelot, G. Bernardi, S. Planes, Reductions in the mitochondrial DNA diversity of coral reef fish provide evidence of population bottlenecks resulting from Holocene sea-level change, Evolution 57 (2003) 1571-1583.

[21] P.M. Buston, C. Fauvelot, M.Y.L. Wong, S. Planes, Genetic relatedness in groups of the humbug damselfish Dascyllus aruanus: small, similar-sized individuals may be close kin, Mol. Ecol. 18 (2009) 47074715.

[22] M.Y.L. Wong, C. Fauvelot, S. Planes, P.M. Buston, Discrete and continuous reproductive tactics in a hermaphroditic society, Anim. Behav. 84 (2012) 897-906.

[23] C. Fauvelot, C. Lemaire, S. Planes, F. Bonhomme, Inferring gene flow in coral reef fishes from different molecular markers: which loci to trust? Heredity 99 (2007) 331-339.

[24] C. Fauvelot, S. Planes, Understanding origins of present-day genetic structure in marine fish: biologically or historically driven patterns? Marine Biology 141 (2002) 773-788.

[25] J.M. Raynal, E.D. Crandall, P.H. Barber, G.N. Mahardika, M.C. Lagman, K.E. Carpenter, Basin isolation and oceanographic features influencing lineage divergence in the humbug damselfish (Dascyllus aruanus) in the Coral Triangle, Bull. Mar. Sci. 90 (2014) 513-532.

[26] S.-Y.V. Liu, F.-T. Chang, P. Borsa, W.-J. Chen, C.-F. Dai, Phylogeography of the humbug damselfish, Dascyllus aruanus (Linnaeus, 1758): evidence of Indo-Pacific vicariance and genetic differentiation of peripheral populations, Biol. J. Linn Soc. 113 (2014) 931-942. DOI: 10.1111/bij.12378

[27] S. McCafferty, E. Bermingham, B. Quenouille, S. Planes, G. Hoelzer, K. Asoh, Historical biogeography and molecular systematics of the Indo-Pacific genus Dascyllus (Teleostei: Pomacentridae), Mol. Ecol. 11 (2002) 1377-1392.

[28] K. Tamura, D. Peterson, N. Peterson, G. Stecher, M. Nei, S. Kumar, MEGA 5: Molecular evolutionary genetics analysis using maximum likelihood, evolutionary distance, and maximum parsimony methods, Mol. Biol. Evol. 28 (2011) 2731-2739.

[29] R. Froese, D. Pauly (eds.), FishBase, World Wide Web electronic publication, www.fishbase.org, version (03/2014), 2014.

[30] K. Belkhir, P. Borsa, L. Chikhi, N. Raufaste, F. Bonhomme, GENETIX version 4.02, logiciel sous Windows ${ }^{\mathrm{TM}}$ pour la génétique des populations, CNRS UMR 5000, Université Montpellier 2, Montpellier, http://www.genetix.univ-montp2.fr/genetix/, 2000.

[31] K. de Queiroz, Species concepts and species delimitation, Syst. Biol. 56 (2007) 879-886.

[32] S. Samadi, A. Barberousse, The tree, the network, and the species, Biol. J. Linn. Soc. 89 (2006) 509-521. 
[33] S. Samadi, A. Barberousse, Species: towards new, well-grounded practices, Biol. J. Linn. Soc. 97 (2009) $217-222$.

[34] C.M. Bull, Ecology of parapatric distributions, Annu. Rev. Ecol. Syst. 22 (1991) 19-36.

[35] P. Forsskål, Descriptiones animalium, avium, amphibiorum, piscium, insectorum, vermium; quae in itinere observavit Petrus Forskål (post mortem auctoris edidit Carsten Niebuhr), adjuncta est medica kahirina atque tabula maris rubri geographica, Mölleri, Hauniae, 1775, xxxiv+164 pp.

[36] R. Fricke, Authorship, availability and validity of fish names described by Peter (Pehr) Simon Forsskål and Johann Christian Fabricius in the 'Descriptiones animalium' by Carsten Niebuhr in 1775 (Pisces), Stuttg. Beitr. Naturk. A, Neue Ser. 1 (2008) 1-76.

[37] E. Rüppell, Atlas zu der Reise im nördlichen Africa, Fische des rothen Meeres, Heinr. Ludw. Brönner, Frankfurt am Main, 1828, 141+iii pp., 35 pls.

[38] A. Günther, Catalogue of the fishes in the British Museum, Volume Fourth, British Museum, London, 1862, xxi+534 pp.

[39] J.E. Randall, Coastal fishes of Oman, Crawford, Bathurst, 1995, xii+439 pp.

[40] J.E. Randall, Reef and shore fishes of the South Pacific: New Caledonia to Tahiti and the Pitcairn Islands, University of Hawai'i Press, Honolulu, 2005, 707 pp.

[41] R. Fricke, P. Durville, G. Bernardi, P. Borsa, G. Mou-Tham, P. Chabanet, Checklist of the shore fishes of Europa Island, Mozambique Channel, southwestern Indian Ocean, including 302 new records, Stuttg. Beitr. Naturk. A, Neue Ser. 6 (2013) 247-276.

[42] W.N. Eschmeyer, Catalog of fishes, electronic version, http:// research.calacademy.org/research/ichthyology/catalog (15 March 2014), 2014.

[43] C. Linnaeus, Systema naturae per regna tria naturae, secundum classes, ordines, species, cum characteribus, differentiis, synonymis, locis, Tomus I, editio decima, reformata, Laurentii Salvii, Stockholm, 1758, ii+824 pp.

[44] S.R. Palumbi, What can molecular genetics contribute to marine biogeography? An urchin's tale, J. Exp. Mar. Biol. Ecol. 203 (1996) 75-92.

[45] R.D. Norris, P.M. Hull, The temporal dimension of marine speciation, Evol. Ecol. 26 (2012) 393-415.

[46] P.Borsa, M. Naciri, L. Bahri, L. Chikhi, F.J. García de León, G. Kotoulas, F. Bonhomme, Zoogéographie infraspécifique de la mer Méditerranée: analyse des données génétiques populationnelles sur seize espèces atlanto-méditerranéennes (poissons et invertébrés), Vie Milieu 47 (1997) 295-305.

[47] L. Bahri-Sfar, C. Lemaire, O.K. Ben Hassine, F. Bonhomme, Fragmentation of sea bass populations in the western and eastern Mediteranean as revealed by microsatellite polymorphism, Proc. R. Soc. Lond. B 267 (2000) 929-935.

[48] A. Rohfritsch, P. Borsa, Genetic structure of Indian scad mackerel Decapterus russelli: Pleistocene vicariance and secondary contact in the central Indo-West Pacific seas, Heredity 95 (2005) 315-322. 
[49] P. Chabanet, P. Durville, Reef fish inventory of Juan de Nova's natural park (western Indian Ocean), West. Ind. Ocean J. Mar. Sci. 4 (2005) 145-162.

[50] P. Chabanet, P. Durville, R. Fricke, H. Amir, L. Vigliola, Checklist of the coral reef fishes of Baa Atoll, Maldives, Atoll. Res. Bull. 590 (2012) 143-162. 
Fig. 1. Summary of phylogeographic data on humbug damselfish (Dascyllus abudafur and D. aruanus). Circle area proportional to sample size. A. Geographic distribution of mitochondrial types from a compilation of published and unpublished sources ([3, 20, 25-27]; present study). Black, Indian-Ocean mitotype characterizing D. abudafur, light-grey, Pacific-Ocean mitotype characterizing D. aruanus. B. Geographic distribution of nuclear types inferred from microsatellite genotypes [26]. Black, genotypes assigned to D. abudafur, grey, genotypes assigned to D. aruanus. C. Pie diagrams representing the frequencies of individuals with black or solid-grey (black), and light-grey or white (light grey) basis of caudal fin.

Fig. 2. Photographs that illustrate the differences in pigmentation patterns between Dascyllus abudafur and $D$. aruanus. A. D. abudafur $64 \mathrm{~mm}$ standard length (SL) from Juan de Nova Island, Mozambique Channel; pigmentation score of the blackish blotch at the basis of caudal fin is 3. B. D. aruanus $45 \mathrm{~mm}$ SL from Raja Ampat, West Papua; pigmentation score is 0.

Fig. 3. Variable nucleotide sites in cytochrome $b$ gene sequences of humbug damselfish, Dascyllus abudafur and D. aruanus. Nucleotide sites numbered from the homologous first nucleotide of the gene in Salmo salar (GENBANK EU492281) and mutations marked using S.-Y.V. Liu et al.'s [26] sequence of the most common haplotype from the Red Sea, RS02 (GENBANK KF754784), as reference. Haplotypes ordered by location of first occurrence, from West to East (Supplementary material, Table S3). Higblighted grey: nucleotide site diagnostic between D. abudafur and D. aruanus; dot: nucleotide identical to reference. 
Fig. 1

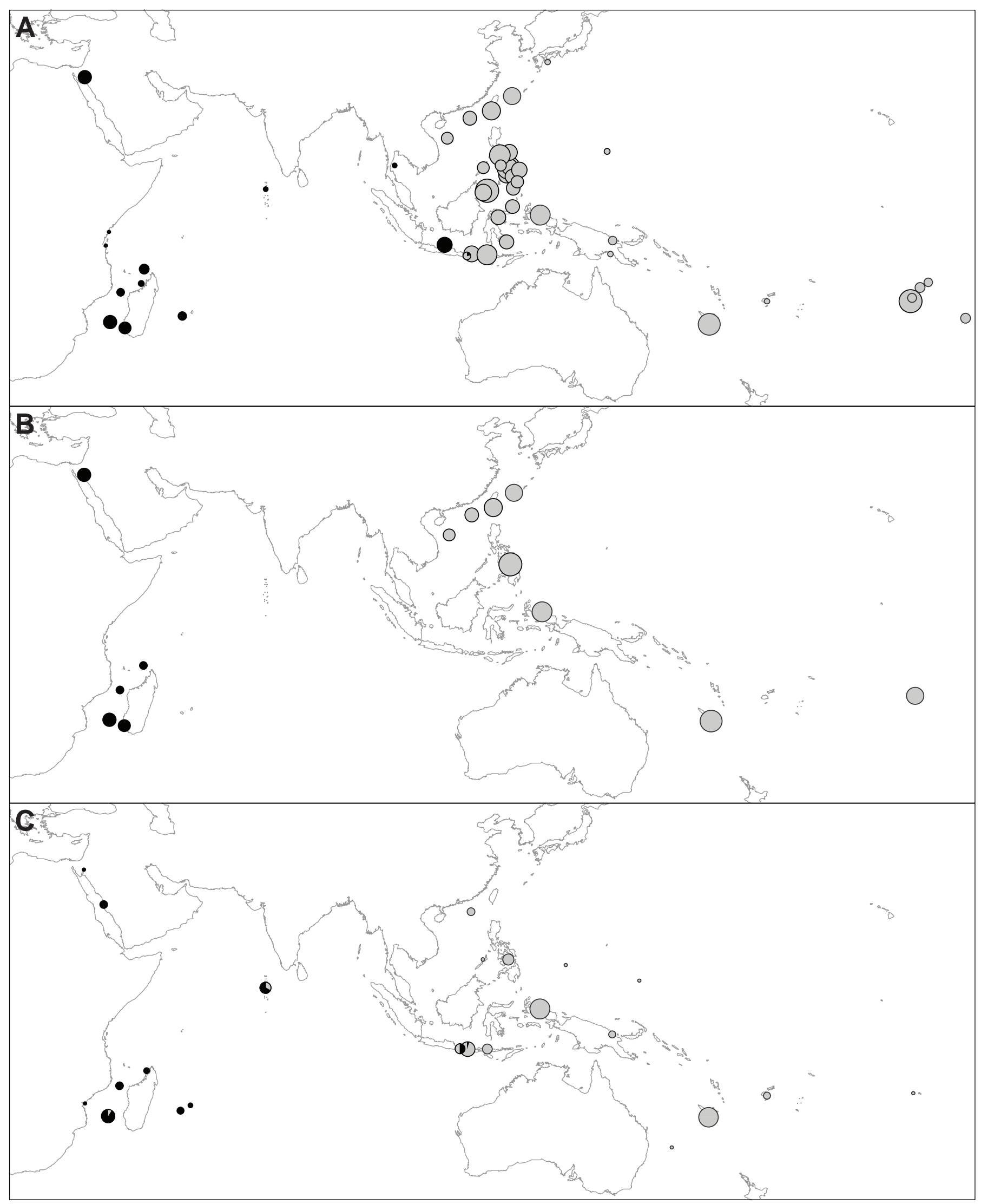


Fig. 2

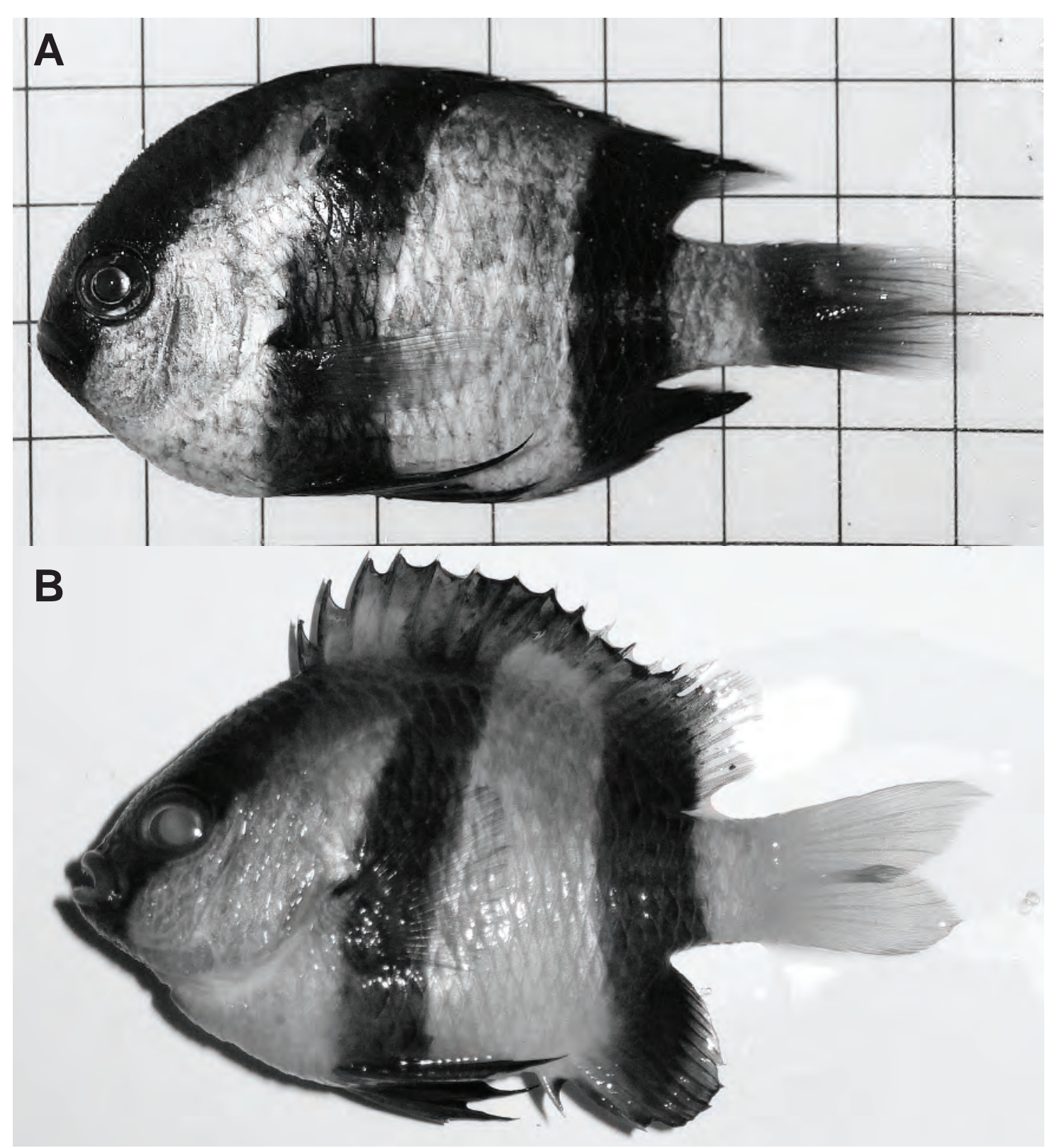




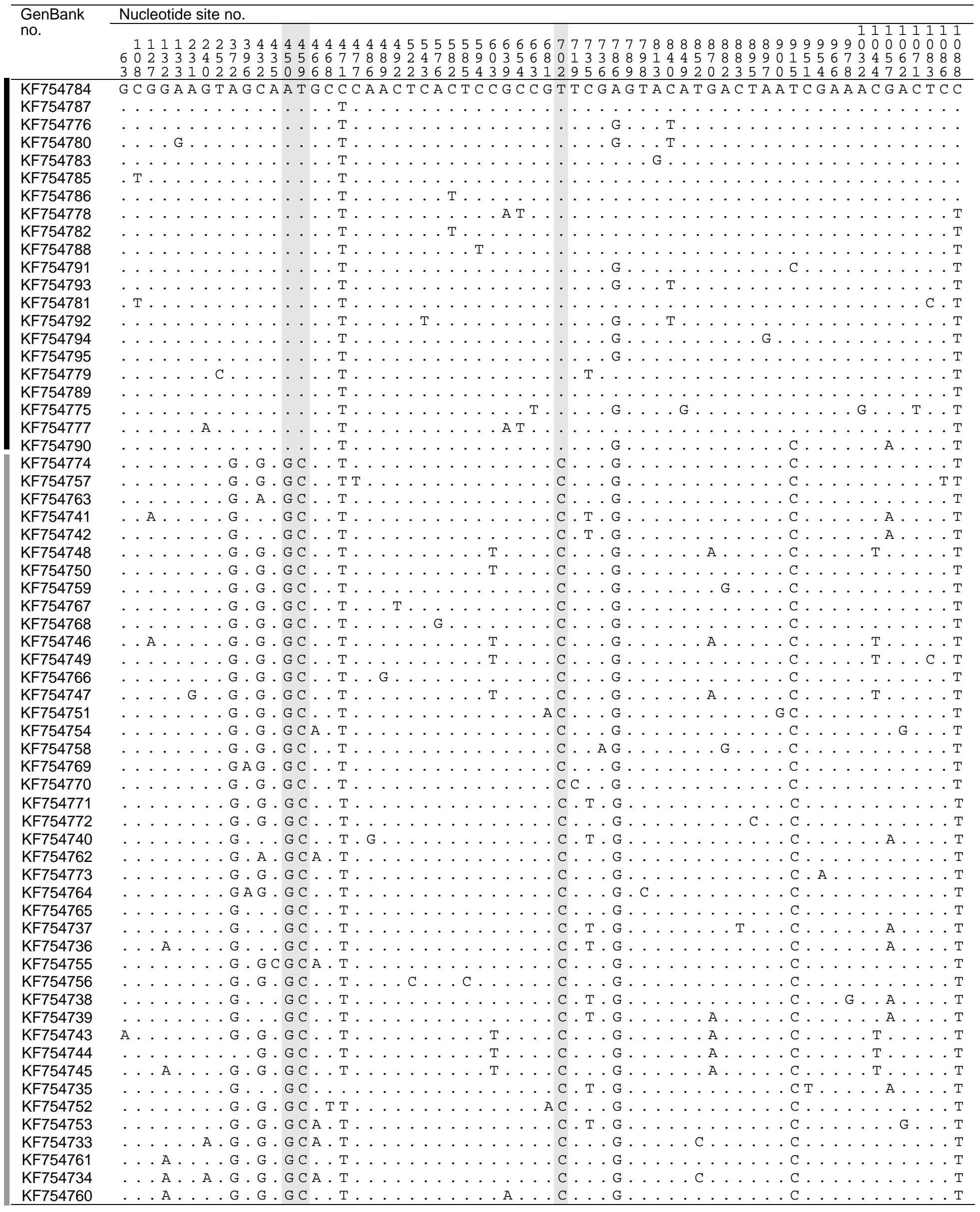




\section{Appendix A.}

Correlation of pairwise $\theta$ estimates at the mitochondrial locus against homologous $\theta$ estimates at 7 microsatellite loci in humbug damselfish (from Supplementary Tables S2 and S3 of [26]). Mantel's test of the correlation between the two matrices: $Z=1.770 ; r=0.869 ; P<0.001$.

\section{Appendix B.}

Supplementary material. 


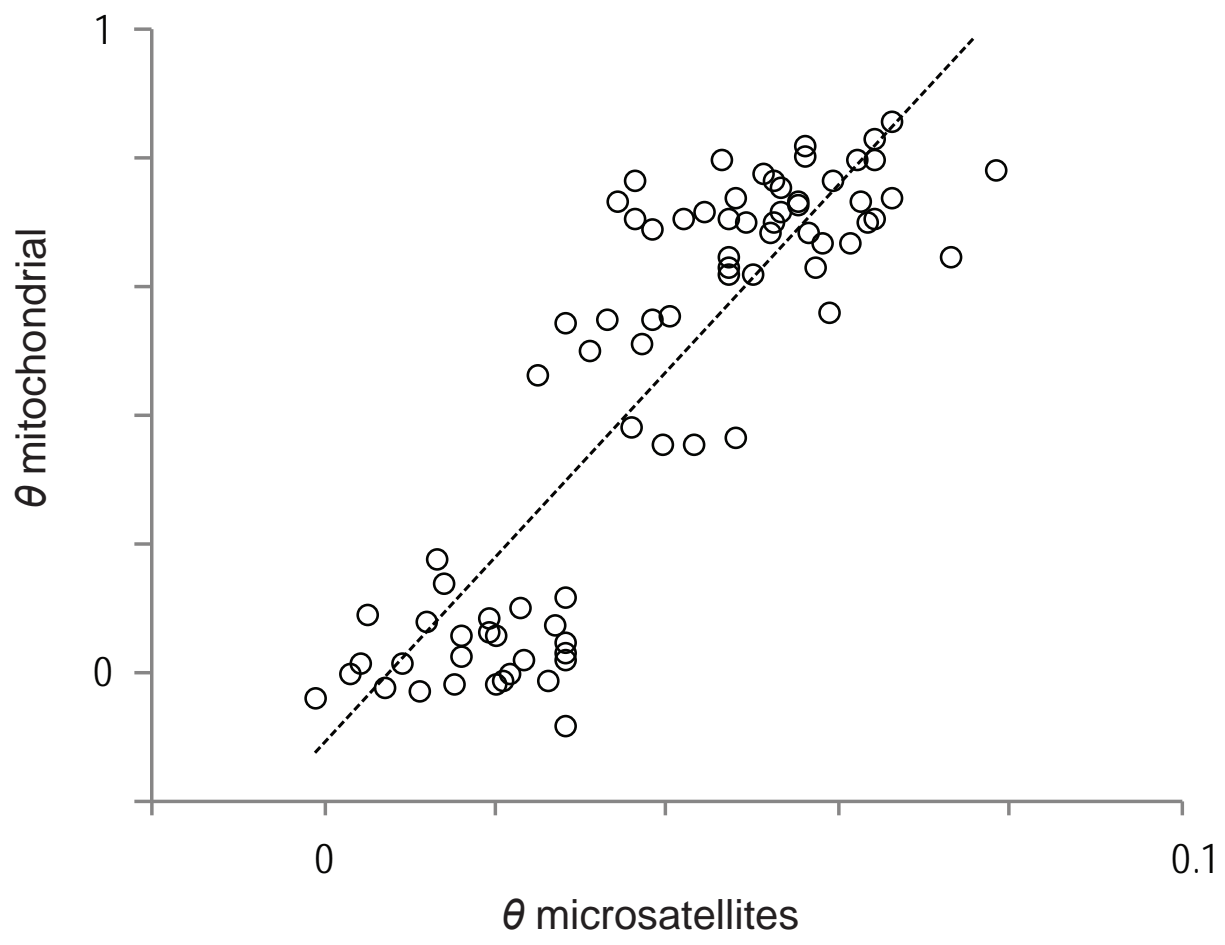




\section{SUPPLEMENTARY MATERIAL}

Resurrection of Indian-Ocean humbug damselfish, Dascyllus abudafur (Forsskål) from synonymy with its Pacific-Ocean sibling, Dascyllus aruanus (L.)

Philippe Borsa*, Andrianus Sembiring, Cécile Fauvelot, Wei-Jen Chen

* Correspondence: philippe.borsa@ird.fr; philippeborsa@gmail.com

Tables S1-S5 and Figs. S1-S7 here appended.

References

G.R. Allen, M.V. Erdmann, Reef fishes of the East Indies, vols. I-III, Tropical Reef Research, Perth, 2012, 1292 pp.

C. Fauvelot, G. Bernardi, S. Planes, Reductions in the mitochondrial DNA diversity of coral reef fish provide evidence of population bottlenecks resulting from Holocene sea-level change, Evolution 57 (2003) 1571-1583.

P. Laboute, R. Grandperrin, Poissons de Nouvelle-Calédonie, Catherine Ledru, Nouméa, 2000, 520 pp.

N. Hubert, C. P.Meyer, H.J. Bruggemann, F. Guérin, R.J. L. Komeno, B. Espiau, R. Causse, J.T. Williams, S. Planes, Cryptic diversity in Indo-Pacific coral-reef fishes revealed by DNA-barcoding provides new support to the Centre-of-Overlap hypothesis, PloS One 7 (2012) e28987.

S.-Y.V. Liu, F.-T. Chang, P. Borsa, W.-J. Chen, C.-F. Dai, Phylogeography of the humbug damselfish, Dascyllus aruanus (Linnaeus, 1758): evidence of Indo-Pacific vicariance and genetic differentiation of peripheral populations, Biol. J. Linn Soc. 113 (2014) 931-942. DOI: 10.1111/bij.12378

S. McCafferty, E. Bermingham, B. Quenouille, S. Planes, G. Hoelzer, K. Asoh, Historical biogeography and molecular systematics of the Indo-Pacific genus Dascyllus (Teleostei: Pomacentridae), Mol. Ecol. 11 (2002) 1377-1392.

J.E. Randall, Randall's tank photos, Collection of 10,000 large-format photos (slides) of dead fishes, 1997a, unpublished.

J.E. Randall, Randall's underwater photos, Collection of almost 2,000 underwater photos (slides), 1997b, unpublished.

J.E. Randall, Reef and shore fishes of the South Pacific: New Caledonia to Tahiti and the Pitcairn Islands, University of Hawai'i Press, Honolulu, 2005, 707 pp.

J.M. Raynal, E.D. Crandall, P.H. Barber, G.N. Mahardika, M.C. Lagman, K.E. Carpenter, Basin isolation and oceanographic features influencing lineage divergence in the humbug damselfish (Dascyllus aruanus) in the Coral Triangle, Bull. Mar. Sci. 90 (2014) 53-532. 
Table S1 List of humbug damselfish (Dascyllus abudafur and D. aruanus) samples used in this article, with frequency of mitochondrial haplotype (either "Indian" or "Pacific"). Samples listed according to geographic location, from West to East. ATP6/8 ATP synthetase 6, 8 gene; CO1 cytochrome-oxidase 1 gene; $C R$ control region; cytb cytochrome b gene; $N$, sample size

\begin{tabular}{|c|c|c|c|c|c|c|}
\hline \multirow{2}{*}{$\begin{array}{l}\text { Region, } \\
\text { Location }\end{array}$} & \multirow[t]{2}{*}{ Site } & \multirow[t]{2}{*}{$N$} & \multirow[t]{2}{*}{ Marker } & \multicolumn{2}{|c|}{ Haplotype frequency } & \multirow[t]{2}{*}{ Reference } \\
\hline & & & & Indian & Pacific & \\
\hline \multicolumn{7}{|l|}{ Indian Ocean } \\
\hline Red Sea & Gulf of Aqaba & 15 & cytb & $100 \%$ & - & Liu et al. (2014) \\
\hline Zanzibar & - & 1 & CR & $100 \%$ & - & present work \\
\hline Kenya & - & 1 & ATP6/8 & $100 \%$ & - & McCafferty et al (2002) \\
\hline Mozambique Channel & Europa I. & 15 & $c y t b$ & $100 \%$ & - & Liu et al. (2014) \\
\hline Mozambique Channel & Juan de Nova I. & 5 & cytb & $100 \%$ & - & Liu et al. (2014) \\
\hline Madagascar & Toliara & 12 & $c y t b$ & $100 \%$ & - & Liu et al. (2014) \\
\hline Mozambique Channel & Nosy Be & 3 & CO1 & $100 \%$ & - & Hubert et al. (2012) \\
\hline Mozambique Channel & Glorieuses Is. & 5 & cytb & $100 \%$ & - & Liu et al. (2014) \\
\hline Mozambique Channel & Glorieuses Is. & 3 & $C R$ & $100 \%$ & - & present work \\
\hline Mascarene Islands & Reunion I. & 2 & ATPG/8 & $100 \%$ & - & McCafferty et al. (2002) \\
\hline Mascarene Islands & Reunion I. & 4 & CO1 & $100 \%$ & - & Hubert et al. (2012) \\
\hline Maldives archipelago & - & 2 & ATPG/8 & $100 \%$ & - & McCafferty et al. (2002) \\
\hline \multicolumn{7}{|l|}{ Coral Triangle } \\
\hline Thailand & - & 2 & ATPG/8 & $100 \%$ & - & McCafferty et al. (2002) \\
\hline Java Sea, Indonesia & Karimunjawa Is. & 19 & $C R$ & $100 \%$ & - & Raynal et al. (2014) \\
\hline Lombok Strait, Indonesia & Serangan & 5 & cytb & $20 \%$ & $80 \%$ & present work \\
\hline South China Sea & Paracels Is. & 12 & cytb & - & $100 \%$ & Liu et al. (2014) \\
\hline Lombok Strait, Indonesia & Gili Is. & 21 & $C R$ & - & $100 \%$ & Raynal et al. (2014) \\
\hline South China Sea & Dongsha I. & 16 & $c y t b$ & - & $100 \%$ & Liu et al. (2014) \\
\hline Sulawesi Sea & Semporna, Sabah & 23 & $C R$ & - & $100 \%$ & Raynal et al. (2014) \\
\hline Sulu Sea & Palawan I. & 12 & $C R$ & - & $100 \%$ & Raynal et al. (2014) \\
\hline Sulawesi Sea & Tawi-Tawi I. & 46 & $C R$ & - & $100 \%$ & Raynal et al. (2014) \\
\hline Flores Sea, Indonesia & Komodo I. & 33 & $C R$ & - & $100 \%$ & Raynal et al. (2014) \\
\hline Taiwan & Houbihu & 27 & cytb & - & $100 \%$ & Liu et al. (2014) \\
\hline Tomimi Bay & Togian Is. & 18 & CR & - & $100 \%$ & Raynal et al. (2014) \\
\hline Sibuyan Sea, Philippines & Romblon & 36 & $C R$ & - & $100 \%$ & Raynal et al. (2014) \\
\hline Sulu Sea & Guimeras & 10 & $C R$ & - & $100 \%$ & Raynal et al. (2014) \\
\hline Bohol Sea, Philippines & Siquijor & 20 & $C R$ & - & $100 \%$ & Raynal et al. (2014) \\
\hline Banda Sea, Indonesia & Wakatobi & 17 & $C R$ & - & $100 \%$ & Raynal et al. (2014) \\
\hline Cebu Strait, Philippines & Caohagan I., Lapu-Lapu & 32 & cytb & - & $100 \%$ & Liu et al. (2014) \\
\hline Cebu Strait, Philippines & Olango & 42 & $C R$ & - & $100 \%$ & Raynal et al. (2014) \\
\hline Philippine Sea & Sorsogon & 21 & $C R$ & - & $100 \%$ & Raynal et al. (2014) \\
\hline Bohol Sea, Philippines & Camiguin & 18 & $C R$ & - & $100 \%$ & Raynal et al. (2014) \\
\hline Philippines & - & 1 & ATP6/8 & - & $100 \%$ & McCafferty et al. (2002) \\
\hline Philippines & - & 5 & $C R$ & - & $100 \%$ & present work \\
\hline Sulawesi Sea & Manado & 16 & $C R$ & - & $100 \%$ & Raynal et al. (2014) \\
\hline Sulawesi Sea & General Santos & 16 & $C R$ & - & $100 \%$ & Raynal et al. (2014) \\
\hline Davao Gulf, Philippines & Davao & 13 & $C R$ & - & $100 \%$ & Raynal et al. (2014) \\
\hline Philippine Sea & Dinagat & 20 & $C R$ & - & $100 \%$ & Raynal et al. (2014) \\
\hline Raja Ampat, West Papua & Pulau Fam & 33 & cytb & - & $100 \%$ & Liu et al. (2014) \\
\hline \multicolumn{7}{|l|}{ Pacific Ocean } \\
\hline Ryukyu archipelago & Sesoko I. & 25 & cytb & - & $100 \%$ & Liu et al. (2014) \\
\hline Japan & - & 2 & ATPG/8 & - & $100 \%$ & McCafferty et al. (2002) \\
\hline Guam & - & 2 & ATPG/8 & - & $100 \%$ & McCafferty et al. (2002) \\
\hline Guam & - & 1 & $C R$ & - & $100 \%$ & present work \\
\hline New Guinea & - & 2 & ATP6/8 & - & $100 \%$ & McCafferty et al. (2002) \\
\hline Bismarck Sea, Papua New Guinea & Madang & 6 & cytb & - & $100 \%$ & present work \\
\hline New Caledonia & - & 2 & ATP6/8 & - & $100 \%$ & McCafferty et al. (2002) \\
\hline New Caledonia & SW Lagoon & 38 & cytb & - & $100 \%$ & Liu et al. (2014) \\
\hline Fiji & - & 2 & CR & - & $100 \%$ & present work \\
\hline Society Islands & Moorea I. & 2 & ATPG/8 & - & $100 \%$ & McCafferty et al. (2002) \\
\hline Society Islands & Moorea I. & 4 & CO1 & - & $100 \%$ & Hubert et al. (2012) \\
\hline Society Islands & Moorea I. & 25 & cytb & - & $100 \%$ & Liu et al. (2014) \\
\hline Society Islands & Moorea I. & 10 & $C R$ & - & $100 \%$ & Fauvelot et al. (2003) \\
\hline Society Islands & Tetiaroa I. & 8 & $C R$ & - & $100 \%$ & Fauvelot et al. (2003) \\
\hline Tuamotu Archipelago & Rangiroa Atoll & 10 & $C R$ & - & $100 \%$ & Fauvelot et al. (2003) \\
\hline Tuamotu Archipelago & Takapoto Atoll & 7 & $C R$ & - & $100 \%$ & Fauvelot et al. (2003) \\
\hline Gambier Archipelago & Marutea Atoll & 10 & $C R$ & - & $100 \%$ & Fauvelot et al. (2003) \\
\hline
\end{tabular}


Table S2 Dascyllus abudafur and D. aruanus. Differences in pigmentation of caudal fin, from photographs of specimens in public repositories, internet sites, and on Figs. S1-S7 here appended. Intensity of pigmentation of the basis of caudal fin was encoded from 3 (blackish) to 0 (no pigmentation). BOLD Barcode of Life Database (http://www.barcodinglife.com/), accessed 18 March 2014; FishBase (http://www.fishbase.org/), accessed 18 March 2014; shaded individuals that also have been sequenced at the mitochondrial locus

\begin{tabular}{|c|c|c|c|c|c|c|}
\hline \multirow{2}{*}{$\begin{array}{l}\text { Individual } \\
\text { no. }\end{array}$} & \multirow[t]{2}{*}{ Origin } & \multirow[t]{2}{*}{ Source } & \multicolumn{4}{|c|}{ Intensity of pigmentation } \\
\hline & & & 0 & 1 & 2 & 3 \\
\hline Daaru-u0 & Red Sea & Randall 1997b & & & & $\mathrm{x}$ \\
\hline Daaru-u4 & Jordan, Red Sea & FishBase & & & $\mathrm{x}$ & \\
\hline- & Jeddah, Red Sea & http://www.oceanfootage.com/ & & & $\mathrm{x}$ & \\
\hline - & Jeddah, Red Sea & http://www.oceanfootage.com/ & & & & $\mathrm{x}$ \\
\hline- & Jeddah, Red Sea & http://www.oceanfootage.com/ & & & & $\mathrm{x}$ \\
\hline- & Jeddah, Red Sea & http://www.oceanfootage.com/ & & & & $\mathrm{x}$ \\
\hline Daaru-u1 & Mozambique, Mozamb. Channel & FishBase & & & & $\mathrm{x}$ \\
\hline Europa 1 & Europa I., Mozamb. Channel & Fig. S1 & & & & $\mathrm{x}$ \\
\hline Europa 2 & Europa I., Mozamb. Channel & Fig. S1 & & & & $\mathrm{x}$ \\
\hline Europa 3 & Europa I., Mozamb. Channel & Fig. S1 & & & & $\mathrm{x}$ \\
\hline Europa 4 & Europa I., Mozamb. Channel & Fig. S1 & & & & $\mathrm{x}$ \\
\hline Europa 5 & Europa I., Mozamb. Channel & Fig. S1 & & & & $\mathrm{x}$ \\
\hline Europa 6 & Europa I., Mozamb. Channel & Fig. S1 & & & $\mathrm{x}$ & \\
\hline Europa 7 & Europa I., Mozamb. Channel & Fig. S1 & & & $\mathrm{x}$ & \\
\hline Europa 8 & Europa I., Mozamb. Channel & Fig. S1 & & & $\mathrm{x}$ & \\
\hline Europa 9 & Europa I., Mozamb. Channel & Fig. S1 & & & $\mathrm{x}$ & \\
\hline Europa 10 & Europa I., Mozamb. Channel & Fig. S1 & & $\mathrm{x}$ & & \\
\hline Europa 11 & Europa I., Mozamb. Channel & Fig. S1 & & $\mathrm{x}$ & & \\
\hline Europa 12 & Europa I., Mozamb. Channel & Fig. S1 & & & $\mathrm{x}$ & \\
\hline Europa 13 & Europa I., Mozamb. Channel & Fig. S1 & & & & $\mathrm{x}$ \\
\hline Europa 14 & Europa I., Mozamb. Channel & Fig. S1 & & & & $\mathrm{x}$ \\
\hline Europa 15 & Europa I., Mozamb. Channel & Fig. S1 & & & & $\mathrm{x}$ \\
\hline JdN 1 & Juan de Nova I., Mozamb. Channel & Fig. S2 & & & & $\mathrm{x}$ \\
\hline $\mathrm{JdN} 2$ & Juan de Nova I., Mozamb. Channel & Fig. S2 & & & & $\mathrm{x}$ \\
\hline $\mathrm{JdN} 3$ & Juan de Nova I., Mozamb. Channel & Fig. S2 & & & & $\mathrm{x}$ \\
\hline $\mathrm{JdN} 4$ & Juan de Nova I., Mozamb. Channel & Fig. S2 & & & & $\mathrm{x}$ \\
\hline $\mathrm{JdN} 5$ & Juan de Nova I., Mozamb. Channel & Fig. S2 & & & & $\mathrm{x}$ \\
\hline NBE 187 & Nosy Be, Mozamb. Channel & BOLD & & & & $\mathrm{x}$ \\
\hline NBE 188 & Nosy Be, Mozamb. Channel & BOLD & & & & $\mathrm{x}$ \\
\hline NBE 189 & Nosy Be, Mozamb. Channel & BOLD & & & & $\mathrm{x}$ \\
\hline REU 0004-01 & Reunion, Mascarene Is. & BOLD & & & & $\mathrm{x}$ \\
\hline REU 0004-02 & Reunion, Mascarene Is. & BOLD & & & & $\mathrm{x}$ \\
\hline REU 2764 & Reunion, Mascarene Is. & BOLD & & & $\mathrm{x}$ & \\
\hline REU 2765 & Reunion, Mascarene Is. & BOLD & & & $\mathrm{x}$ & \\
\hline Daaru-u5 & Mauritius, Mascarene Is. & FishBase & & & $\mathrm{x}$ & \\
\hline Daaru-u6 & Mauritius, Mascarene Is. & FishBase & & & $\mathrm{x}$ & \\
\hline- & Maldives & http://www.travelswithhok.com & & & & $\mathrm{x}$ \\
\hline- & Maldives & http://www.travelswithhok.com & & & & $\mathrm{x}$ \\
\hline- & Maldives & http://www.travelswithhok.com & & & & $\mathrm{x}$ \\
\hline- & Maldives & http://www.travelswithhok.com & & & & $\mathrm{x}$ \\
\hline- & Maldives & http://www.travelswithhok.com & & & & $\mathrm{x}$ \\
\hline- & Maldives & http://www.travelswithhok.com & & & $\mathrm{x}$ & \\
\hline- & Maldives & http://www.travelswithhok.com & & & $\mathrm{x}$ & \\
\hline- & Maldives & http://www.travelswithhok.com & & $\mathrm{x}$ & & \\
\hline- & Maldives & http://www.travelswithhok.com & & $\mathrm{x}$ & & \\
\hline- & Maldives & http://www.travelswithhok.com & & $\mathrm{x}$ & & \\
\hline Bali 1 & Singaraja, Bali & Fig. S2 & & & $\mathrm{x}$ & \\
\hline Bali 2 & Singaraja, Bali & Fig. S2 & & & & $\mathrm{x}$ \\
\hline Bali 3 & Singaraja, Bali & Fig. S2 & & & & $\mathrm{x}$ \\
\hline IBRC 11.01.08 & Serangan, western Lombok Strait & Fig. S6 & & $\mathrm{x}$ & & \\
\hline IBRC 11.01.14 & Serangan, western Lombok Strait & Fig. S6 & & & & $\mathrm{x}$ \\
\hline IBRC 11.01 .22 & Serangan, western Lombok Strait & Fig. S6 & & $\mathrm{x}$ & & \\
\hline IBRC 11.01.27 & Serangan, western Lombok Strait & Fig. S6 & & $\mathrm{x}$ & & \\
\hline IBRC 11.01 .28 & Serangan, western Lombok Strait & Fig. S6 & $\mathrm{x}$ & & & \\
\hline Lombok 1 & Gili Gede, eastern Lombok Strait & Fig. S7 & $\mathrm{x}$ & & & \\
\hline Lombok 2 & Gili Gede, eastern Lombok Strait & Fig. S7 & $\mathrm{x}$ & & & \\
\hline Lombok 3 & Gili Gede, eastern Lombok Strait & Fig. S7 & $\mathrm{x}$ & & & \\
\hline
\end{tabular}


Table S2 (continued)

\begin{tabular}{|c|c|c|c|c|c|c|}
\hline \multirow{2}{*}{$\begin{array}{l}\text { Individual } \\
\text { no. }\end{array}$} & \multirow[t]{2}{*}{ Origin } & \multirow[t]{2}{*}{ Source } & \multicolumn{4}{|c|}{ Intensity of pigmentation } \\
\hline & & & 0 & 1 & 2 & 3 \\
\hline Lombok 4 & Gili Gede, eastern Lombok Strait & Fig. S7 & $\mathrm{x}$ & & & \\
\hline Lombok 5 & Gili Gede, eastern Lombok Strait & Fig. S7 & $\mathrm{x}$ & & & \\
\hline Lombok 6 & Gili Gede, eastern Lombok Strait & Fig. S7 & $\mathrm{x}$ & & & \\
\hline Lombok 7 & Gili Gede, eastern Lombok Strait & Fig. S7 & $\mathrm{x}$ & & & \\
\hline Lombok 8 & Gili Gede, eastern Lombok Strait & Fig. S7 & $\mathrm{x}$ & & & \\
\hline Lombok 9 & Gili Gede, eastern Lombok Strait & Fig. S7 & $\mathrm{x}$ & & & \\
\hline Lombok 10 & Gili Gede, eastern Lombok Strait & Fig. S7 & $\mathrm{x}$ & & & \\
\hline Lombok 11 & Gili Gede, eastern Lombok Strait & Fig. S7 & & & $\mathrm{x}$ & \\
\hline Lombok 12 & Gili Gede, eastern Lombok Strait & Fig. S7 & $\mathrm{x}$ & & & \\
\hline Lombok 13 & Gili Layar, eastern Lombok Strait & Fig. S7 & $\mathrm{x}$ & & & \\
\hline Lombok 14 & Gili Layar, eastern Lombok Strait & Fig. S7 & $\mathrm{x}$ & & & \\
\hline Lombok 15 & Gili Layar, eastern Lombok Strait & Fig. S7 & $\mathrm{x}$ & & & \\
\hline Lombok 16 & Gili Layar, eastern Lombok Strait & Fig. S7 & $\mathrm{x}$ & & & \\
\hline Lombok 17 & Gili Layar, eastern Lombok Strait & Fig. S7 & $\mathrm{x}$ & & & \\
\hline Lombok 18 & Gili Layar, eastern Lombok Strait & Fig. S7 & $\mathrm{x}$ & & & \\
\hline- & Komodo I., Flores Sea & http://www.sfups.org/ & $\mathrm{x}$ & & & \\
\hline- & Komodo I., Flores Sea & http://www.sfups.org/ & $\mathrm{x}$ & & & \\
\hline- & Komodo I., Flores Sea & http://www.sfups.org/ & $\mathrm{x}$ & & & \\
\hline- & Komodo I., Flores Sea & http://www.sfups.org/ & $\mathrm{x}$ & & & \\
\hline- & Komodo I., Flores Sea & http://www.sfups.org/ & $\mathrm{x}$ & & & \\
\hline- & Komodo I., Flores Sea & http://www.sfups.org/ & $\mathrm{x}$ & & & \\
\hline- & Komodo I., Flores Sea & http://www.sfups.org/ & $\mathrm{x}$ & & & \\
\hline- & Komodo I., Flores Sea & http://www.sfups.org/ & $\mathrm{x}$ & & & \\
\hline 042913-06 & Dongsha., South China Sea & Fig. S2 & $\mathrm{x}$ & & & \\
\hline WJC2243 & Dongsha., South China Sea & Fig. S2 & $\mathrm{x}$ & & & \\
\hline DS 1 & Dongsha., South China Sea & Fig S4 & $\mathrm{x}$ & & & \\
\hline DS 2 & Dongsha., South China Sea & Fig S4 & $\mathrm{x}$ & & & \\
\hline DS 3 & Dongsha., South China Sea & Fig S4 & $\mathrm{x}$ & & & \\
\hline HLC-10828 & Philippines & BOLD & $\mathrm{x}$ & & & \\
\hline HLC-10829 & Philippines & BOLD & $\mathrm{x}$ & & & \\
\hline HLC-10830 & Philippines & BOLD & & $\mathrm{x}$ & & \\
\hline HLC-10831 & Philippines & BOLD & & $\mathrm{x}$ & & \\
\hline Daaru-u2 & Palawan, Philippines & FishBase & $\mathrm{x}$ & & & \\
\hline Daaru-u3 & Philippines & Randall (1997a) & & $\mathrm{x}$ & & \\
\hline LL 1 & Lapu-Lapu I., Philippines & Fig S4 & $\mathrm{x}$ & & & \\
\hline LL 2 & Lapu-Lapu I., Philippines & Fig S4 & $\mathrm{x}$ & & & \\
\hline LL 3 & Lapu-Lapu I., Philippines & Fig S4 & $\mathrm{x}$ & & & \\
\hline LL 4 & Lapu-Lapu I., Philippines & Fig S4 & $\mathrm{x}$ & & & \\
\hline LL 5 & Lapu-Lapu I., Philippines & Fig S4 & $\mathrm{x}$ & & & \\
\hline- & Pulau Pef, Raja Ampat, West Papua & http:// faroutphotos.com & $\mathrm{x}$ & & & \\
\hline Sayonek 1 & Pulau Sayonek, Raja Ampat & Fig. $2 \mathrm{~B}$ & $\mathrm{x}$ & & & \\
\hline Fam 1 & Pulau Fam, Raja Ampat, West Papua & Fig. S3 & & $\mathrm{x}$ & & \\
\hline Fam 2 & Pulau Fam, Raja Ampat, West Papua & Fig. S3 & $\mathrm{x}$ & & & \\
\hline Fam 3 & Pulau Fam, Raja Ampat, West Papua & Fig. S3 & $\mathrm{x}$ & & & \\
\hline Fam 4 & Pulau Fam, Raja Ampat, West Papua & Fig. S3 & & $\mathrm{x}$ & & \\
\hline Fam 5 & Pulau Fam, Raja Ampat, West Papua & Fig. S3 & $\mathrm{x}$ & & & \\
\hline Fam 6 & Pulau Fam, Raja Ampat, West Papua & Fig. S3 & $\mathrm{x}$ & & & \\
\hline Fam 7 & Pulau Fam, Raja Ampat, West Papua & Fig. S3 & $\mathrm{x}$ & & & \\
\hline Fam 8 & Pulau Fam, Raja Ampat, West Papua & Fig. S3 & $\mathrm{x}$ & & & \\
\hline Fam 9 & Pulau Fam, Raja Ampat, West Papua & Fig. S3 & $\mathrm{x}$ & & & \\
\hline Fam 10 & Pulau Fam, Raja Ampat, West Papua & Fig. S3 & $\mathrm{x}$ & & & \\
\hline Fam 11 & Pulau Fam, Raja Ampat, West Papua & Fig. S3 & $\mathrm{x}$ & & & \\
\hline Fam 12 & Pulau Fam, Raja Ampat, West Papua & Fig. S3 & $\mathrm{x}$ & & & \\
\hline Fam 13 & Pulau Fam, Raja Ampat, West Papua & Fig. S3 & $\mathrm{x}$ & & & \\
\hline Fam 14 & Pulau Fam, Raja Ampat, West Papua & Fig. S3 & $\mathrm{x}$ & & & \\
\hline Fam 15 & Pulau Fam, Raja Ampat, West Papua & Fig. S3 & $\mathrm{x}$ & & & \\
\hline Fam 16 & Pulau Fam, Raja Ampat, West Papua & Fig. S3 & & $\mathrm{x}$ & & \\
\hline Fam 17 & Pulau Fam, Raja Ampat, West Papua & Fig. S3 & $\mathrm{x}$ & & & \\
\hline Fam 18 & Pulau Fam, Raja Ampat, West Papua & Fig. S3 & $\mathrm{x}$ & & & \\
\hline Fam 19 & Pulau Fam, Raja Ampat, West Papua & Fig. S3 & $\mathrm{x}$ & & & \\
\hline Fam 20 & Pulau Fam, Raja Ampat, West Papua & Fig. S3 & & $\mathrm{x}$ & & \\
\hline Fam 21 & Pulau Fam, Raja Ampat, West Papua & Fig. S3 & $\mathrm{x}$ & & & \\
\hline Fam 22 & Pulau Fam, Raja Ampat, West Papua & Fig. S3 & $\mathrm{x}$ & & & \\
\hline Fam 23 & Pulau Fam, Raja Ampat, West Papua & Fig. S3 & $\mathrm{x}$ & & & \\
\hline
\end{tabular}


Table S2 (continued)

\begin{tabular}{|c|c|c|c|c|c|c|}
\hline \multirow{2}{*}{$\begin{array}{l}\text { Individual } \\
\text { no. }\end{array}$} & \multirow[t]{2}{*}{ Origin } & \multirow[t]{2}{*}{ Source } & \multicolumn{4}{|c|}{ Intensity of pigmentation } \\
\hline & & & 0 & 1 & 2 & 3 \\
\hline Fam 24 & Pulau Fam, Raja Ampat, West Papua & Fig. S3 & $\mathrm{x}$ & & & \\
\hline Fam 25 & Pulau Fam, Raja Ampat, West Papua & Fig. S3 & $\mathrm{x}$ & & & \\
\hline Fam 26 & Pulau Fam, Raja Ampat, West Papua & Fig. S3 & $\mathrm{x}$ & & & \\
\hline Fam 27 & Pulau Fam, Raja Ampat, West Papua & Fig. S3 & $\mathrm{x}$ & & & \\
\hline Fam 28 & Pulau Fam, Raja Ampat, West Papua & Fig. S3 & $\mathrm{x}$ & & & \\
\hline Fam 29 & Pulau Fam, Raja Ampat, West Papua & Fig. S3 & $\mathrm{x}$ & & & \\
\hline Fam 30 & Pulau Fam, Raja Ampat, West Papua & Fig. S3 & $\mathrm{x}$ & & & \\
\hline Fam 31 & Pulau Fam, Raja Ampat, West Papua & Fig. S3 & $\mathrm{x}$ & & & \\
\hline Fam 32 & Pulau Fam, Raja Ampat, West Papua & Fig. S3 & $\mathrm{x}$ & & & \\
\hline Fam 33 & Pulau Fam, Raja Ampat, West Papua & Fig. S3 & $\mathrm{x}$ & & & \\
\hline PR161-1 & Madang., Bismarck Sea & Fig S2 & $\mathrm{x}$ & & & \\
\hline PR161-2 & Madang., Bismarck Sea & Fig S2 & $\mathrm{x}$ & & & \\
\hline PR161-3 & Madang., Bismarck Sea & Fig S2 & $\mathrm{x}$ & & & \\
\hline PR161-4 & Madang., Bismarck Sea & Fig S2 & $\mathrm{x}$ & & & \\
\hline- & Chuuk & Allen and Erdmann (2012) & $\mathrm{x}$ & & & \\
\hline- & Yap & http://reefguide.org/ & $\mathrm{x}$ & & & \\
\hline- & Lord Howe I. & Randall (2005) & $\mathrm{x}$ & & & \\
\hline- & New Caledonia & Laboute and Grandperrin (2000) & $\mathrm{x}$ & & & \\
\hline- & New Caledonia & Laboute and Grandperrin (2000) & $\mathrm{x}$ & & & \\
\hline- & New Caledonia & Laboute and Grandperrin (2000) & $\mathrm{x}$ & & & \\
\hline- & New Caledonia & Laboute and Grandperrin (2000) & $\mathrm{x}$ & & & \\
\hline- & New Caledonia & Laboute and Grandperrin (2000) & $\mathrm{x}$ & & & \\
\hline- & New Caledonia & Laboute and Grandperrin (2000) & $\mathrm{x}$ & & & \\
\hline- & New Caledonia & Laboute and Grandperrin (2000) & $\mathrm{x}$ & & & \\
\hline- & New Caledonia & Laboute and Grandperrin (2000) & $\mathrm{x}$ & & & \\
\hline- & New Caledonia & Laboute and Grandperrin (2000) & $\mathrm{x}$ & & & \\
\hline- & New Caledonia & Laboute and Grandperrin (2000) & $\mathrm{x}$ & & & \\
\hline- & New Caledonia & Laboute and Grandperrin (2000) & $\mathrm{x}$ & & & \\
\hline- & New Caledonia & Laboute and Grandperrin (2000) & $\mathrm{x}$ & & & \\
\hline Poé 1 & Poé, New Caledonia & Fig. S4 & $\mathrm{x}$ & & & \\
\hline Poé 2 & Poé, New Caledonia & Fig. S4 & $\mathrm{x}$ & & & \\
\hline Poé 3 & Poé, New Caledonia & Fig. S4 & $\mathrm{x}$ & & & \\
\hline Poé 4 & Poé, New Caledonia & Fig. S4 & $\mathrm{x}$ & & & \\
\hline Poé 5 & Poé, New Caledonia & Fig. S4 & $\mathrm{x}$ & & & \\
\hline Poé 6 & Poé, New Caledonia & Fig. S4 & $\mathrm{x}$ & & & \\
\hline Poé 7 & Poé, New Caledonia & Fig. S4 & $\mathrm{x}$ & & & \\
\hline Poé 8 & Poé, New Caledonia & Fig. S4 & $\mathrm{x}$ & & & \\
\hline Poé 9 & Poé, New Caledonia & Fig. S4 & $\mathrm{x}$ & & & \\
\hline Poé 10 & Poé, New Caledonia & Fig. S4 & $\mathrm{x}$ & & & \\
\hline SWLagoon 1 & SW lagoon, New Caledonia & Fig. S5 & $\mathrm{x}$ & & & \\
\hline SWLagoon 2 & SW lagoon, New Caledonia & Fig. S5 & $\mathrm{x}$ & & & \\
\hline SWLagoon 3 & SW lagoon, New Caledonia & Fig. S5 & $\mathrm{x}$ & & & \\
\hline SWLagoon 4 & SW lagoon, New Caledonia & Fig. S5 & $\mathrm{x}$ & & & \\
\hline SWLagoon 5 & SW lagoon, New Caledonia & Fig. S5 & $\mathrm{x}$ & & & \\
\hline SWLagoon 6 & SW lagoon, New Caledonia & Fig. S5 & $\mathrm{x}$ & & & \\
\hline SWLagoon 7 & SW lagoon, New Caledonia & Fig. S5 & $\mathrm{x}$ & & & \\
\hline SWLagoon 8 & SW lagoon, New Caledonia & Fig. S5 & $\mathrm{x}$ & & & \\
\hline SWLagoon 9 & SW lagoon, New Caledonia & Fig. S5 & $\mathrm{x}$ & & & \\
\hline SWLagoon 10 & SW lagoon, New Caledonia & Fig. S5 & $\mathrm{x}$ & & & \\
\hline Muaivuso 1 & Viti Levu, Fiji & Fig. S4 & & $\mathrm{x}$ & & \\
\hline Muaivuso 2 & Viti Levu, Fiji & Fig. S4 & $\mathrm{x}$ & & & \\
\hline Muaivuso 3 & Viti Levu, Fiji & Fig. S4 & $\mathrm{x}$ & & & \\
\hline Muaivuso 4 & Viti Levu, Fiji & Fig. S4 & $\mathrm{x}$ & & & \\
\hline MBIO 556_1 & Moorea, Society Is. & BOLD & $\mathrm{x}$ & & & \\
\hline
\end{tabular}


Table S3 Humbug damselfish, Dascyllus abudafur and D. aruanus. Cytochrome $b$ gene haplotype frequency per sample. Abbreviations for samples as in Liu et al. (2014); other abbreviation: $M A$ Madang, Bismarck Sea; $N$ sample size; $n$ frequency of haplotype in total sample. Samples listed according to geographic location, from West to East

\begin{tabular}{|c|c|c|c|c|c|c|c|c|c|c|c|c|c|c|c|}
\hline \multirow[t]{2}{*}{ GENBANK no. } & \multicolumn{14}{|c|}{ Sample } & \multirow[t]{2}{*}{$n$} \\
\hline & RS & EU & JN & MD & GL & PI & DS & TW & LL & SK & $\mathrm{RA}$ & $\mathrm{MA}$ & $\mathrm{NC}$ & SI & \\
\hline KF754784 & 6 & & & & & & & & & & & & & & 6 \\
\hline KF754787 & 4 & & & & & & & & & & & & & & 4 \\
\hline KF754776 & 1 & & & & & & & & & & & & & & 1 \\
\hline KF754780 & 1 & & & & & & & & & & & & & & 1 \\
\hline KF754783 & 1 & & & & & & & & & & & & & & 1 \\
\hline KF754785 & 1 & & & & & & & & & & & & & & 1 \\
\hline KF754786 & 1 & & & & & & & & & & & & & & 1 \\
\hline KF754778 & & 3 & 1 & 1 & & & & & & & & & & & 5 \\
\hline KF754782 & & 2 & 2 & 3 & & & & & & & & & & & 7 \\
\hline KF754788 & & 2 & & 2 & & & & & & & & & & & 4 \\
\hline KF754791 & & 2 & & 1 & 1 & & & & & & & & & & 4 \\
\hline KF754793 & & 2 & & 1 & & & & & & & & & & & 3 \\
\hline KF754781 & & 1 & 1 & 1 & 1 & & & & & & & & & & 4 \\
\hline KF754792 & & 1 & & & & & & & & & & & & & 1 \\
\hline KF754794 & & 1 & 1 & & & & & & & & & & & & 2 \\
\hline KF754795 & & 1 & & 1 & & & & & & & & & & & 2 \\
\hline KF754779 & & & & 1 & & & & & & & & & & & 1 \\
\hline KF754789 & & & & 1 & & & & & & & & & & & 1 \\
\hline KF754775 & & & & & 1 & & & & & & & & & & 1 \\
\hline KF754777 & & & & & 1 & & & & & & & & & & 1 \\
\hline KF754790 & & & & & 1 & & & & & & & & & & 1 \\
\hline KF754774 & & & & & & 6 & 6 & 15 & 13 & 10 & 10 & & 1 & & 61 \\
\hline KF754757 & & & & & & 2 & & & & & & & & & 2 \\
\hline KF754763 & & & & & & 2 & 1 & 1 & & & & & & & 4 \\
\hline KF754741 & & & & & & 1 & & & & & & & & & 1 \\
\hline KF754742 & & & & & & 1 & 1 & 3 & 5 & 6 & 13 & 3 & 8 & & 40 \\
\hline KF754748 & & & & & & & 4 & 1 & 3 & 5 & 1 & 1 & 11 & & 26 \\
\hline KF754750 & & & & & & & 1 & 4 & 2 & & 2 & 2 & & & 11 \\
\hline KF754759 & & & & & & & 1 & & 1 & 1 & & & & & 3 \\
\hline KF754767 & & & & & & & 1 & & & & & & & & 1 \\
\hline KF754768 & & & & & & & 1 & & & & & & & & 1 \\
\hline KF754746 & & & & & & & & 1 & & & & & & & 1 \\
\hline KF754749 & & & & & & & & 1 & & & & & & & 1 \\
\hline KF754766 & & & & & & & & 1 & & & 1 & & & & 2 \\
\hline KF754747 & & & & & & & & & 1 & & & & & & 1 \\
\hline KF754751 & & & & & & & & & 1 & & & & & & 1 \\
\hline KF754754 & & & & & & & & & 1 & & & & & & 1 \\
\hline KF754758 & & & & & & & & & 1 & & & & & & 1 \\
\hline KF754769 & & & & & & & & & 1 & & & & 1 & 2 & 4 \\
\hline KF754770 & & & & & & & & & 1 & & & & & & 1 \\
\hline KF754771 & & & & & & & & & 1 & & & & & & 1 \\
\hline KF754772 & & & & & & & & & 1 & & & & & & 1 \\
\hline KF754740 & & & & & & & & & & 1 & & & & & 1 \\
\hline KF754762 & & & & & & & & & & 1 & & & & & 1 \\
\hline KF754773 & & & & & & & & & & 1 & & & & & 1 \\
\hline KF754764 & & & & & & & & & & & 2 & & & & 2 \\
\hline KF754765 & & & & & & & & & & & 1 & & & & 1 \\
\hline KF754737 & & & & & & & & & & & 1 & & & & 1 \\
\hline KF754736 & & & & & & & & & & & 1 & & & & 1 \\
\hline KF754755 & & & & & & & & & & & 1 & & & & 1 \\
\hline KF754756 & & & & & & & & & & & & & 6 & & 6 \\
\hline KF754738 & & & & & & & & & & & & & 4 & & 4 \\
\hline KF754739 & & & & & & & & & & & & & 1 & & 1 \\
\hline KF754743 & & & & & & & & & & & & & 1 & & 1 \\
\hline KF754744 & & & & & & & & & & & & & 1 & & 1 \\
\hline KF754745 & & & & & & & & & & & & & 1 & & 1 \\
\hline KF754735 & & & & & & & & & & & & & 1 & & 1 \\
\hline KF754752 & & & & & & & & & & & & & 1 & & 1 \\
\hline KF754753 & & & & & & & & & & & & & 1 & & 1 \\
\hline KF754733 & & & & & & & & & & & & & & 19 & 19 \\
\hline KF754761 & & & & & & & & & & & & & & 2 & 2 \\
\hline KF754734 & & & & & & & & & & & & & & 1 & 1 \\
\hline KF754760 & & & & & & & & & & & & & & 1 & 1 \\
\hline$N$ & 15 & 15 & 5 & 12 & 5 & 12 & 16 & 27 & 32 & 25 & 33 & 6 & 38 & 25 & 266 \\
\hline
\end{tabular}


Table S4 Partial cytochrome- $b$ gene sequences (in FASTA format) of 5 humbug damselfish individuals from Serangan, western Lombok Strait

\begin{abstract}
Sequence
>IBRC 110114 Serangan

A T G G C C AGCT T C C G C A A A A C T C A C C C A C T G C T T A A A G C A G C A A A T A T G C A G T A TCG A C CTGCCTACGCCATCCAACATCTCTGTCTGATGGAACTTTGGCTCCCTCCTAGGACTCTGCT

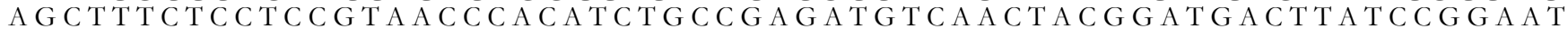
A TACACGCTAACGGCGCATCCTTCTTCTTTATCTGCATCTACCTCCACATCGGACGA GGAC TCTACTACGGCTCATTCCTTCACAAAGAGACATGAAACGTAGGAGTAATCCTCCTCCTCTT

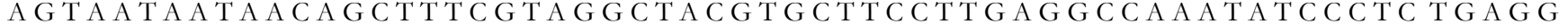
TGCCACCGTA A TCACA A ACCTCCTA TCAGCCTT TCCCTACGTCGGTGATTCCCTAGTCCA A GAATCTGA G G G G GCT TCTCAGTAGACA A T GCCACTCTCACCCGATTCTTTGCC TTCCACTT

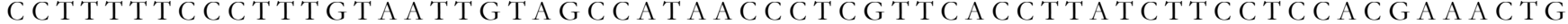

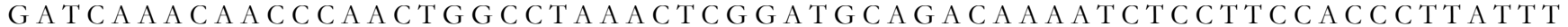
CTCCTACAAGGACA TCCTCGGCTTTGCAGTTCTGCTACTAGCACTAATT TCACTAGCACTA TTCGCCCCCA A T T TCTCGGA G A C C C C G A C A A T TC

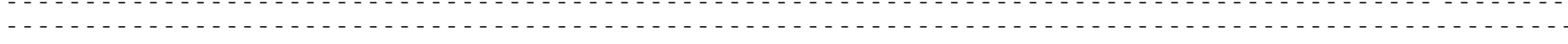

>IBRC 110127 Serangan

A T G GCCAGCTTCCGCAAAACTCACCCACTGCTTAAA GCA GCAAA T GA T GCA GTAATCGAC CTGCCTACGCCATCCAACATCTCTGTCTGATGGAACTTTGGCTCCCTCCTAGGACTCTGCT TAATCGCCCAGATCCTCACAGGCCTCTTTCTCGCCATACATTATACATCA GATATCGCCACA GCTTTCTCCTCCGTAACCCACATCTGCCGAGATGTCAACTACGGATGACTTATCCGG AATA TACACGCTAACGGCGCATCCTTCTTCTTTATCTGCATCTACCTCCACATCGGACGA TGACT CTACTACGGCTCATTCCTTCACAAAGAGACA TGAAACGTAGGAGTA TC T C T C CTCTTA GTAATGATAACA GCTTTCGTAGGCTACGTGCTTCCTTGA GGCCA A A T A T C C C TCT TA GGT GCCACCGTAATCACAAACCTCCTGTCAGCCTTCCCCTACGTCGGTGATTCCCTAGTCCAAT GAATCTGAGGGGGCTTCTCAGTAGACAATGCCACTCTCACC CGATTCTTTGCCTTCCACT T C CTTTTTCCCTTTGTAATTGTAGCCATAACCCTCGTTCACCTTATCTTCCTC CACGAAACTG GATCAAACAACCCAACTGGCCTAAACTCGGATGCAGACAAAATCTCCTTCCACCCTTATTT CTCCTACAAGGACATCCTCGGCTTTGCAGTCCTGCTACTAGCACTAATT TCACTAGCACTA TTTGCCCCCAATCTTCTCGGAGACC C CGACA A T TCATCCCCGCTAAC C C A TGGTGACAC C A C C T C A C

$>$ IBRC 110122 Serangan

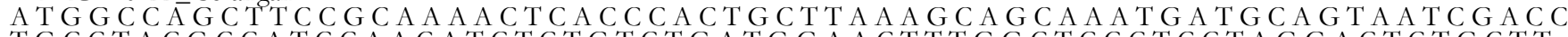
TGCCTACGCCA TCCAACA TCTCTGTCTGATGGAACT T T G GCTCCCTCCTAGGACTCTGCT T A A T C GCCCA G T C C T A C A G GCCTCT T T C T C GCCA T A C A T T A T A C A T A G T A TCGCCACA

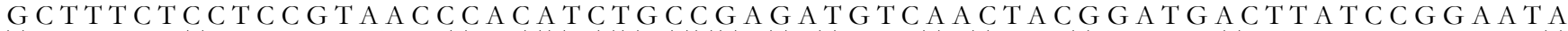
TACACGCTAACGGCGCATCCT TCT TCT T T A TCTGCATCTACCTCCACA TCGGACGAGGACT

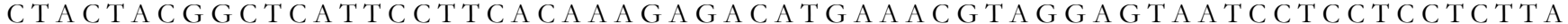

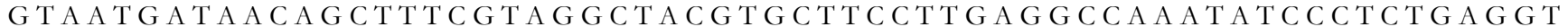
GCCACGGTA A TCACA A A CCTCCTGTCAGCCTTCCCCTACGTCGGTGATTCCCTAGTCCAAT GAATCTGAGGGGGCTTCTCAGTAGACAATGCCACTCTCACCCGATTCTTTGCCTTCCACTT

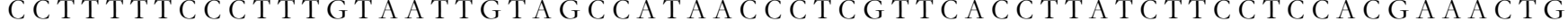

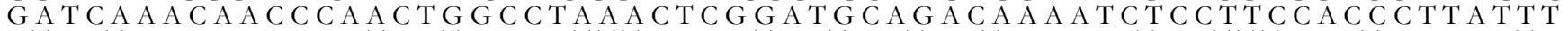
CTCCTACAAGGACA TCCTCGGCTTTGCAGTCCTGCTACTAGCACTAATTTCACTAGCACTA

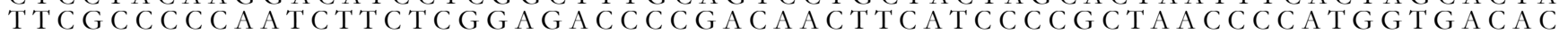
C A C C T C A C

$>$ IBRC 110128

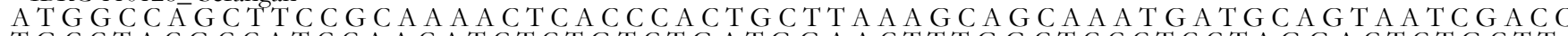

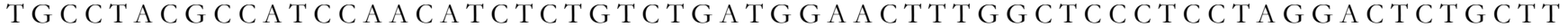
A A T C GCCCA G T C C T A C A G GCCTC T T T C T C GCCA T A C A T T A A C A TCA G T A TCGCCACA GCT T TCTCCTCCGTAACCCACA TCTGCCGAGATG TCAACTACGGATGACT TA TCCGGAATA TACACGCTAACGGCGCATCCTTCT TCT T TA TCTGCATCTACCTCCACATCGGACGAGGACT CTACTACGGCTCA TTCCTTCACA A A GA GACATGAAACGTAGGAGTAATCCTCCTCCTCTTA

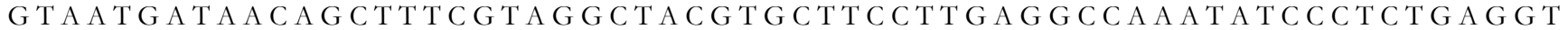
GCCACGGTA A TCACA A A CCTCCTGTCAGCCTTCCCCTACGTCGGTGATTCCCTAGTCCAAT

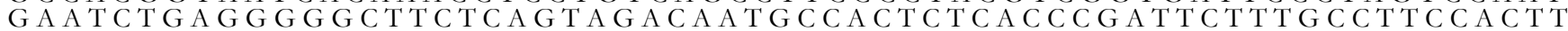

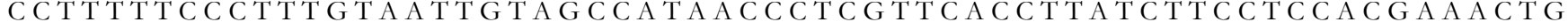
GATCAAACA A C C CA A C TGGCCTAAACTCGGATGCA GACA A A TCTCCTTCCACCCTTATT T CTCCTACAA G GACA TCCTCGGCTTTGCA T TCCTGCTACTAGCACTAATTTCACTA GCACTA T T C G C C C C C A A T C T T C TCG G A G A C C C C G A C A A C T T C A T C C C C G C TA A C C C A T G T T A C A C C A C C T C A C

$>$ IBRC 110108

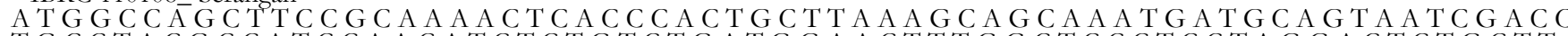

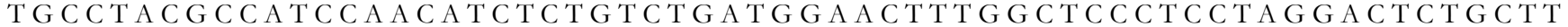

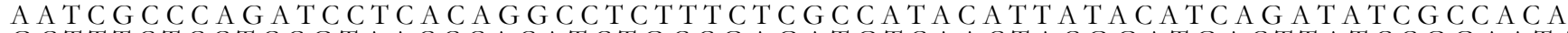
GCTTTCTCCTCCGTAACCCACATCTGCCGAGATGTCAACTACGGATGACTTATCCGGAATA TACACGCTAACGGCGCATCCTTCTTCT T TA TCTGCATCTACCTCCACATCGGACGAGGACT C TACTACGGCTCATTCCTTCACAAAGAGACATGAAACGTAGGAGTAATCCTCCTCCTCT A

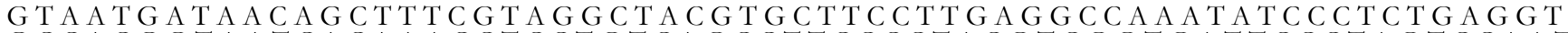
GCCACGGTAATCACAAACCTCCTGTCAGCCTTCCCCTACGTCGGTGATTCCCTAGTCCAAT GAATCTGAGGGGGCTTCTCAGTAGACAATGCCACTCTCACCCGATTCTTTGCCTTCCACTT 
C CTTTTTCCCTTTGTAATTGTAGCCATAACCCTCGTTCACCTTATCTTCCTCCACGAAACTG GATCAAACAACCCAACTGGCCTAAACTCGGATGCAGACAAAATCTCCTTCCACCCTTATTT CTCCTACAAGGACATCCTCGGCTTTGCAGTCCTGCTACTAGCACTAATTTCACTAGCACTA

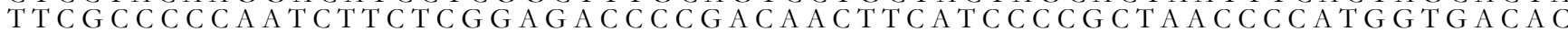

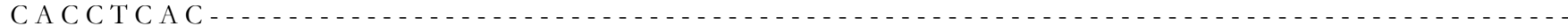

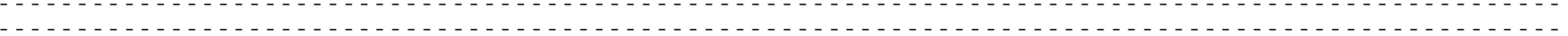

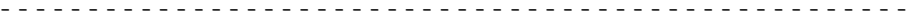


Table S5 Partial control-region sequences (in FASTA format) of humbug damselfish, Dascyllus abudafur and $D$. aruanus

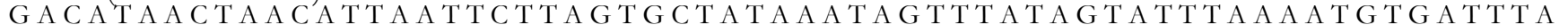
A A A T T TGAATCT TACAACTCAACACCTGTTT-GTAGCA TTATCCCATA A GCT TGCACCGCT ACGTGCATA TATGTACATTCACCATA A T T TATATTA ACCATATCATAGATATTTA T T T A T TGATTTCAAGCTTTAACTAATACCAAAGTCAAAGGACA TACTTGTTTTGAAACATTCACCT GAATA A A A GCACA TA A ACCTCTACATG TA TCA A A A A TA A G G G TACAATTAAAGATTTA A GATTTAACCGTTACATACTCATGGGTTCAGATATACCAAGTATTCAGTACCTCTGCAAGT

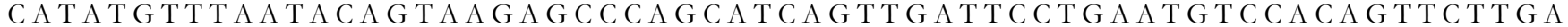
T G G T C A A G G A C A G A A T A A $>\mathrm{G}$ lor2 (Glorieuses Islands)

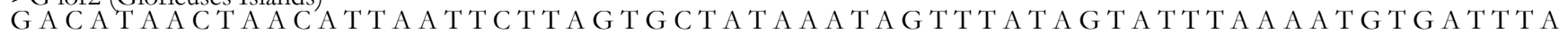

A A A A TGTGA A TCT TACA A C TCA ACACCTGTTT-GTAGCATTATCCCATA A GCTTGCACCGCT

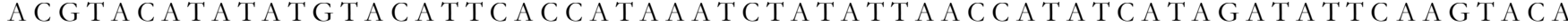

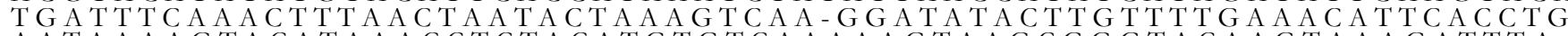
A A T A A A A G T A C A T A A C C TCT A C A T G T G T A A A A A G T A G C G G G T A C A A T A A G A T T A A GATTCA ACTGTTACATACTCATGA TTCAGATATACCAAGTATTCAGTACCTCTGCAAGT

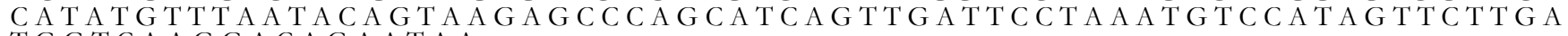
T G G T C A A G G A CA G A A A A

$>$ Glor3 (Glorieuses Islands)

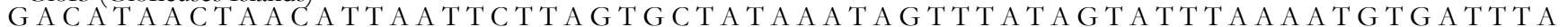
A A A A T T T A A TCT TACA ACTCAACACCTGTTT-GTAGCATTATTCCATAAGCT TGCACCGCT

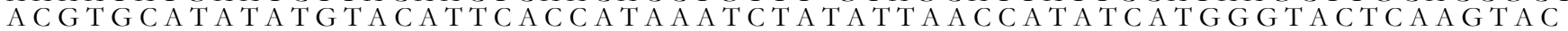
A TGATTTCA A A TTTGACTAATATTAAAGTCAA-GGATATA T T T T T T TAAGGCATTTACCT

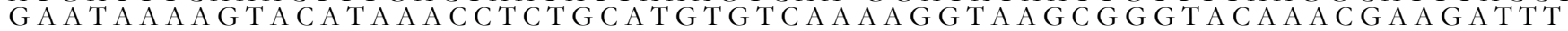

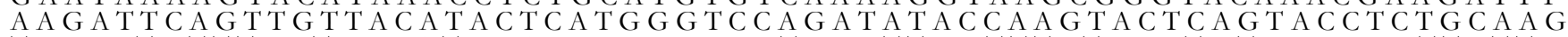

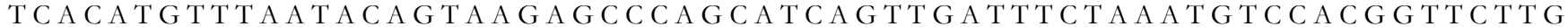
A T G G T C A A G G A C A G A A T A A

Dascyllus aruanus

$>$ Phil5 (Philippines)
}

TACA A C T C A A C A C C T G

TTTTGTAGCATTATTCCATAAGCTTGCACTTCTACGTGCATATATGTATATTCACCATGAAT

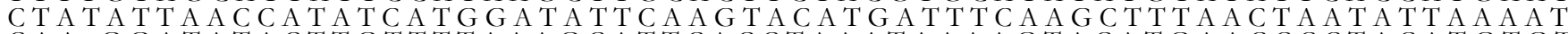
C A A-GG A T A T A C T T G T T T T A A A GCA T T C A C C TA A A T A A A A T A CA T G A C C C T A C A T T T T C A A A A G G T A A G C GGGCA C A A G T A A A A T T T A A G A C T C A A C C G T T A C A T A C T A TGGG TCT A G A T A T A C CA A G T A T T C A G TAC C T C T G C A A G T C A C A T G T T T A A T A C A G T A G A G C C A G C A TCA G TTG A T T TCT A A A . . . . . . . . . . . . . . . . . . .

$>$ Phil11 (Philippines)

T A C A A C T CA A C A C - T G TTTTGTAGCATTATTCCATA A GCTTGCACTTCTACGTGCATATATGTATATTCACCATAAAT

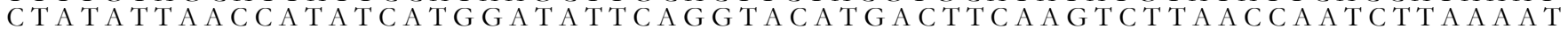

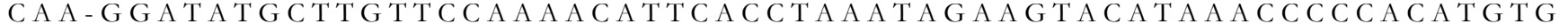
TCGAAAGGTAAACGAGTACA A G T A A A A T T T A A G T T TA ACCGTTACA TAC TCA T GA T TC

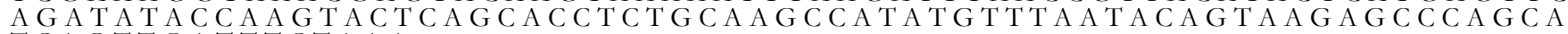
T C A G T T G A T T T C T A A A . . . . . . . . . . . . . . . . . . .

$>$ Phil12 (Philippines)

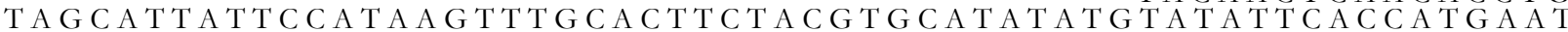
CTATATTAACCATATCATGGATATTCGAGTACATGATTTCAAGCTTTAACTAATCTTAAAAT

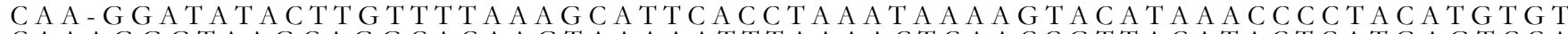
CA A A G G TAAGCAGGCACAAGTAAAAATTTAAAACTCAACCGTTACATACTCATGAGTCCA GA T A T A C C A A G T A T T C A T A C C T C T G C A A G T A C A T G T T T A A T A C A G T A G A G C C A G A T C A G T T G A T T T C T A A A - ....-

$>$ Phil13 (Philippines)

T TTTTGTAGCA TTA TTCCATAAGCTTGCACTTCTACGTGCATA TATGTATATTCACCATGAAT

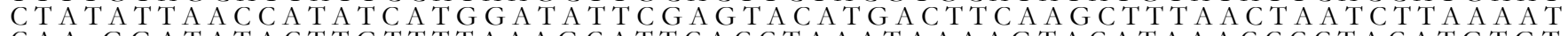
CAA-GGATATACTTGTTTTAAAGCATTCACCTAAATAAAAGTACATAAACCCCTACATGTGT

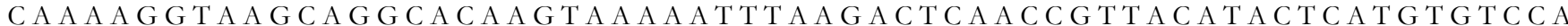

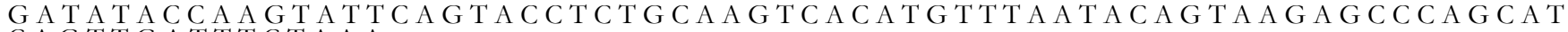
C A G T T G A T T T C T A A A . . . . . . . . . . . . . . . . . .

$>$ Phil20 (Philippines)

TACA A C T C A A C A C C T G TTTTGTAGCATTATTCCATAAGCTTGCACTTCTACGTGCATATATGTATATTCACCATGAAT C TA TA T TA A C CA TA TCATGGGTATTCGAGTACATGATTTCAAGCTTTAACTAATCTTAAAA

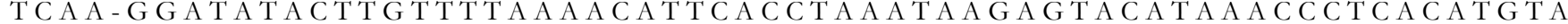

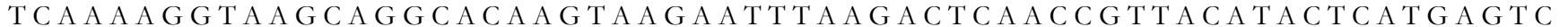
A A GATATACCAAGTATTCAGTACCTCTGCAAGTCACATGTTTAATACAGTAAGAGCCCAGC A TCA G TTG A T T T C TA A A . . . . . . . . . . . . . . . . . .

$>$ Guam17 (Guam)

T A C A A C T C A A C A C C T G TTTTGTA GCATTATTCCATAAGCTTGCACTTCTACGTGCATATATGTATATTCACCATGAAT

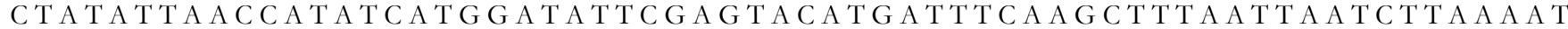


C A A - G G A T A T A C T T G T T T TA A A GCA T T C A C C T A A A T A A A G TA C A T A A C C C T A C T T T G C

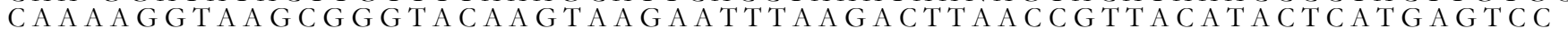
A GA TA T A C CA A GCACTCAGCACCTCTGCA A TCACA T T T TA TACAGTAAGAGCCCAGCA

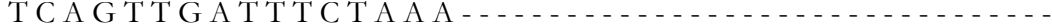

$>$ Fiji14 (Fiji Islands) TT T T T A 作 CA T T C TGGATATTCGAGTACATGATTTCAAGCTTCAACTAATTCTAAAAT 作 CAAAAGGTAAGCAAGGACAAGTAAAAATTTAAGACTCAACCGTTACATACTCACGAGTCC

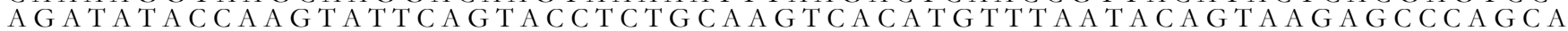
T C A G TTGA T T TC TA A A . . . . . . . . . . . . . . . . . . . . .

$>$ Fiji18 (Fiji Islands) (T)

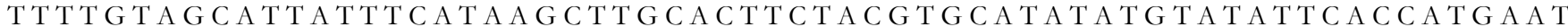

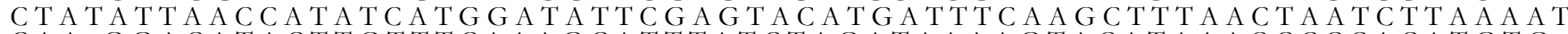
CAA-GGACA TACTTGTT TCAAAGCA T T TA TCTAGATAAAAGTACATAAACCCCCACATGTG TCA A A GG TA A GCAGGCACAAGTAA A A T T TA A G T TCAACCGTTACATACTCACAAGTCC

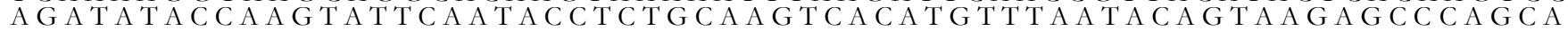
T C A G T T GA T T TC T A A A . . . . . . . . . . . . . . . . . . . 


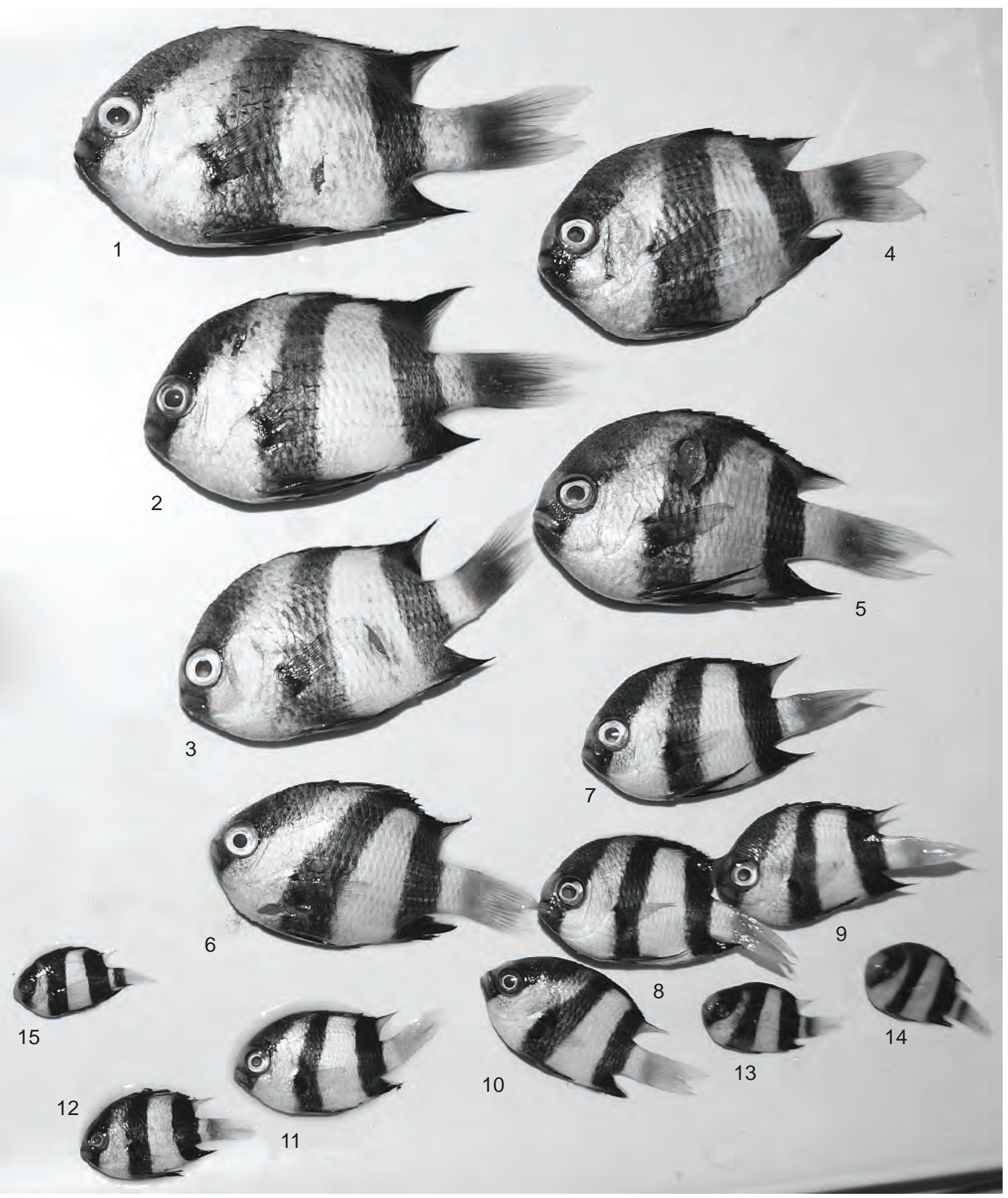

Fig. S1 Dascyllus abudafur. Individuals no Europa 1-15 from Europa Island, Mozambique Channel, 06 April 2011 (WJC). 

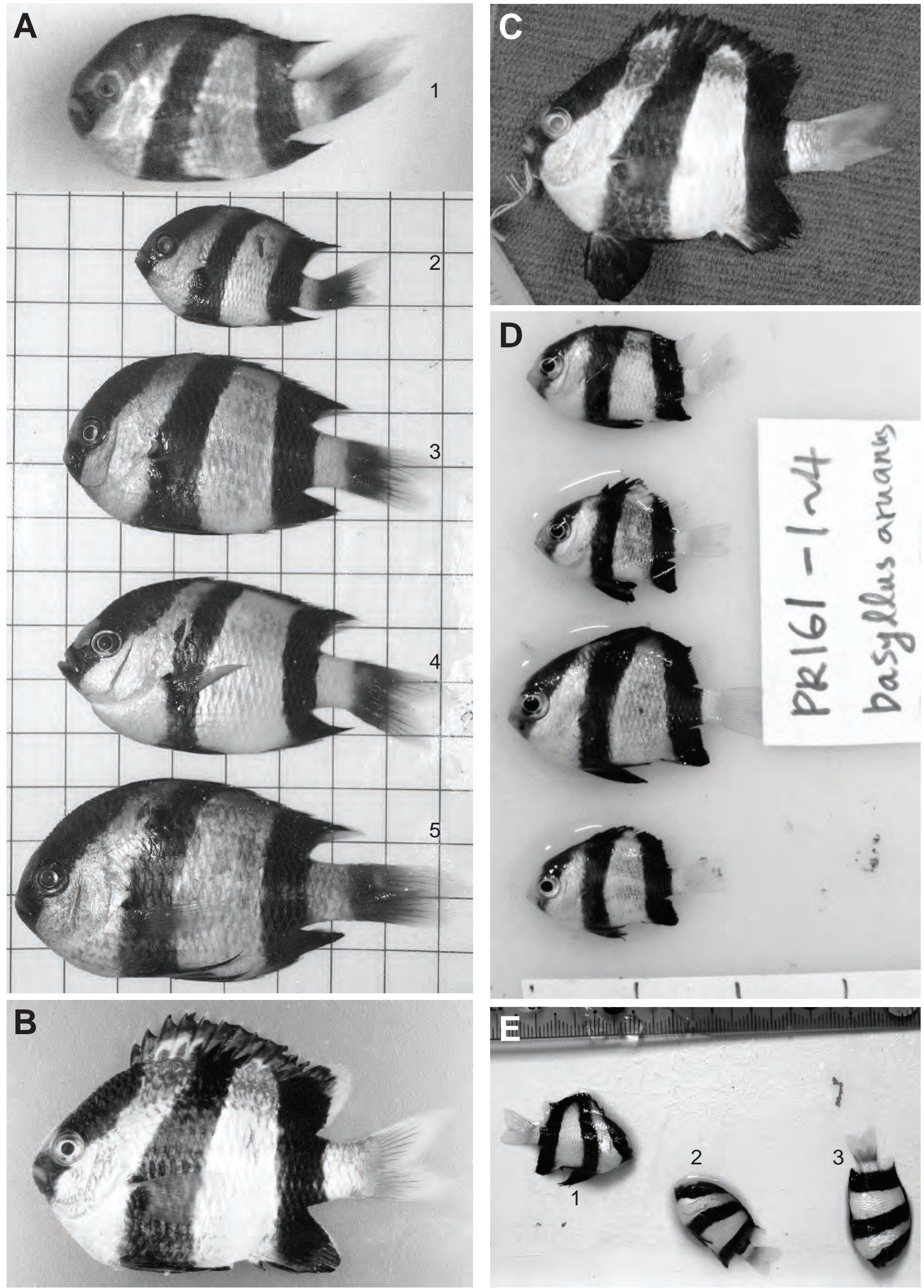

Fig. S2 Humbug damselfish. A Dascyllus abudafur, individuals nos. JdN 1-5 from Juan de Nova Island, Mozambique Channel, 11-12 April 2011 (PB, WJC). B Dascyllus aruanus, individual no. 042913-06 from Dongsha, South China Sea, 29 April 2013 (WJC). C Dascyllus aruanus, individual no. WJC2243 from Dongsha, South China Sea, 09 May 2013 (WJC). D Dascyllus aruanus, individuals nos. PR161-1 to 4 from Madang, Bismarck Sea, Papua New Guinea, December 2012 (WJC). E Dascyllus abudafur, individuals nos. Bali 1-3 from Singaraja, Bali Island, April 2014 (PB, AS). 


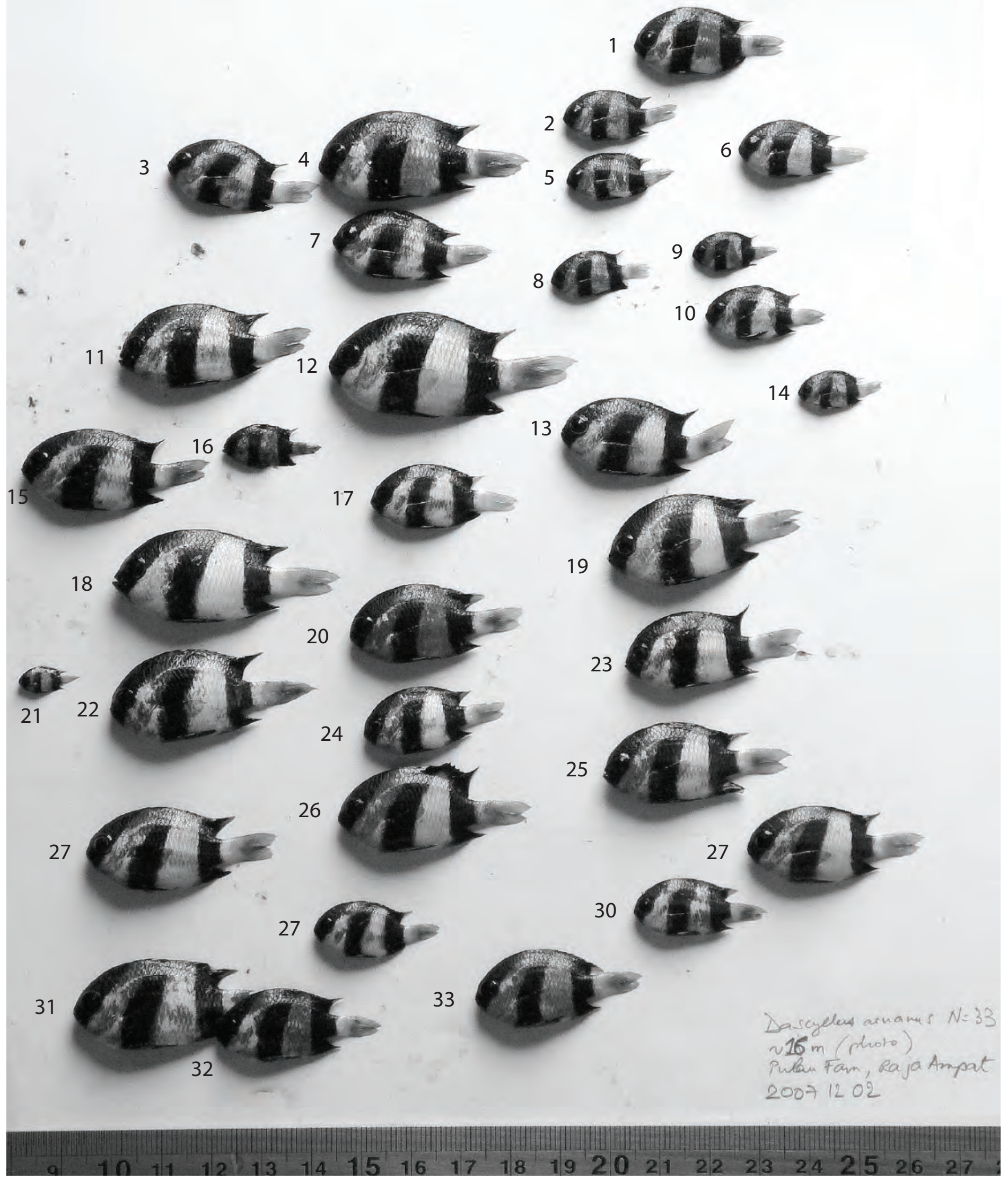

Fig. S3 Dascyllus aruanus. Individuals nos. Fam 1-33 from Pulau Fam, Raja Ampat, West Papua, 02 December 2007 (PB). 

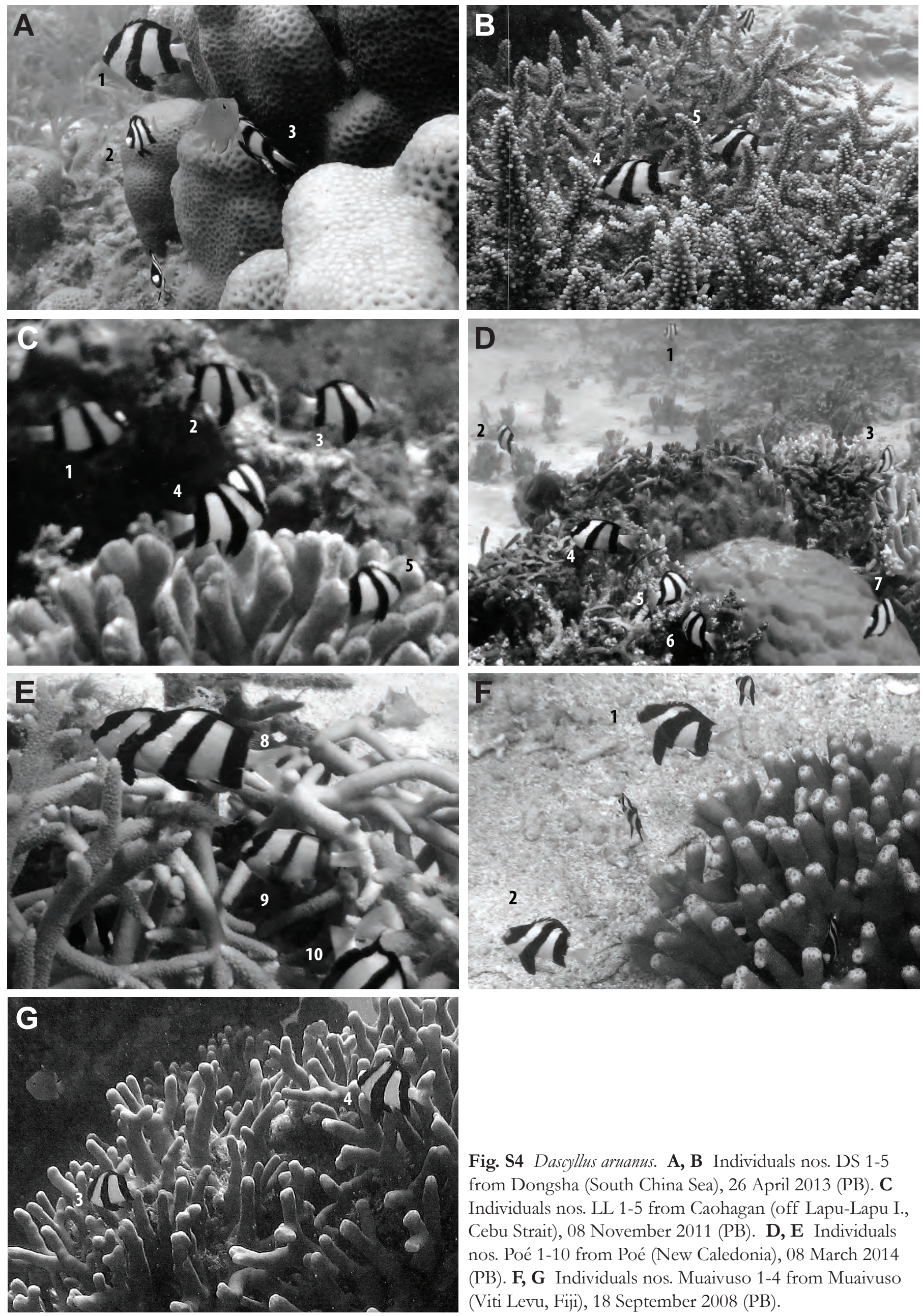

Fig. S4 Dascyllus aruanus. A, B Individuals nos. DS 1-5 from Dongsha (South China Sea), 26 April 2013 (PB). C Individuals nos. LL 1-5 from Caohagan (off Lapu-Lapu I., Cebu Strait), 08 November 2011 (PB). D, E Individuals nos. Poé 1-10 from Poé (New Caledonia), 08 March 2014 (PB). F, G Individuals nos. Muaivuso 1-4 from Muaivuso (Viti Levu, Fiji), 18 September 2008 (PB). 

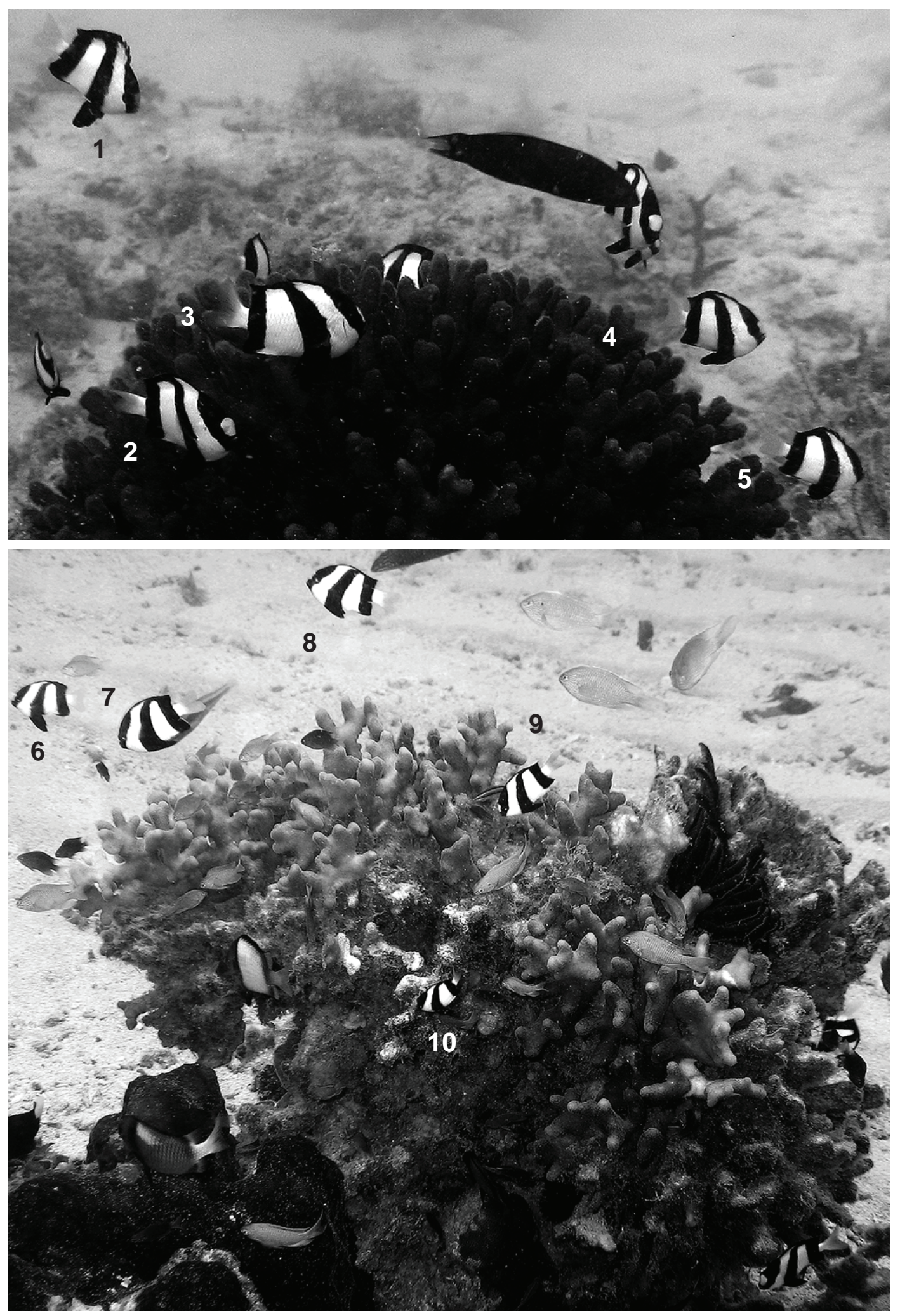

Fig. S5 Dascyllus aruanus. Individuals nos. SWLagoon 1-10 from the southwestern lagon of New Caledonia. A 14 March 2008 (PB). B 07 April 2008 (PB). 

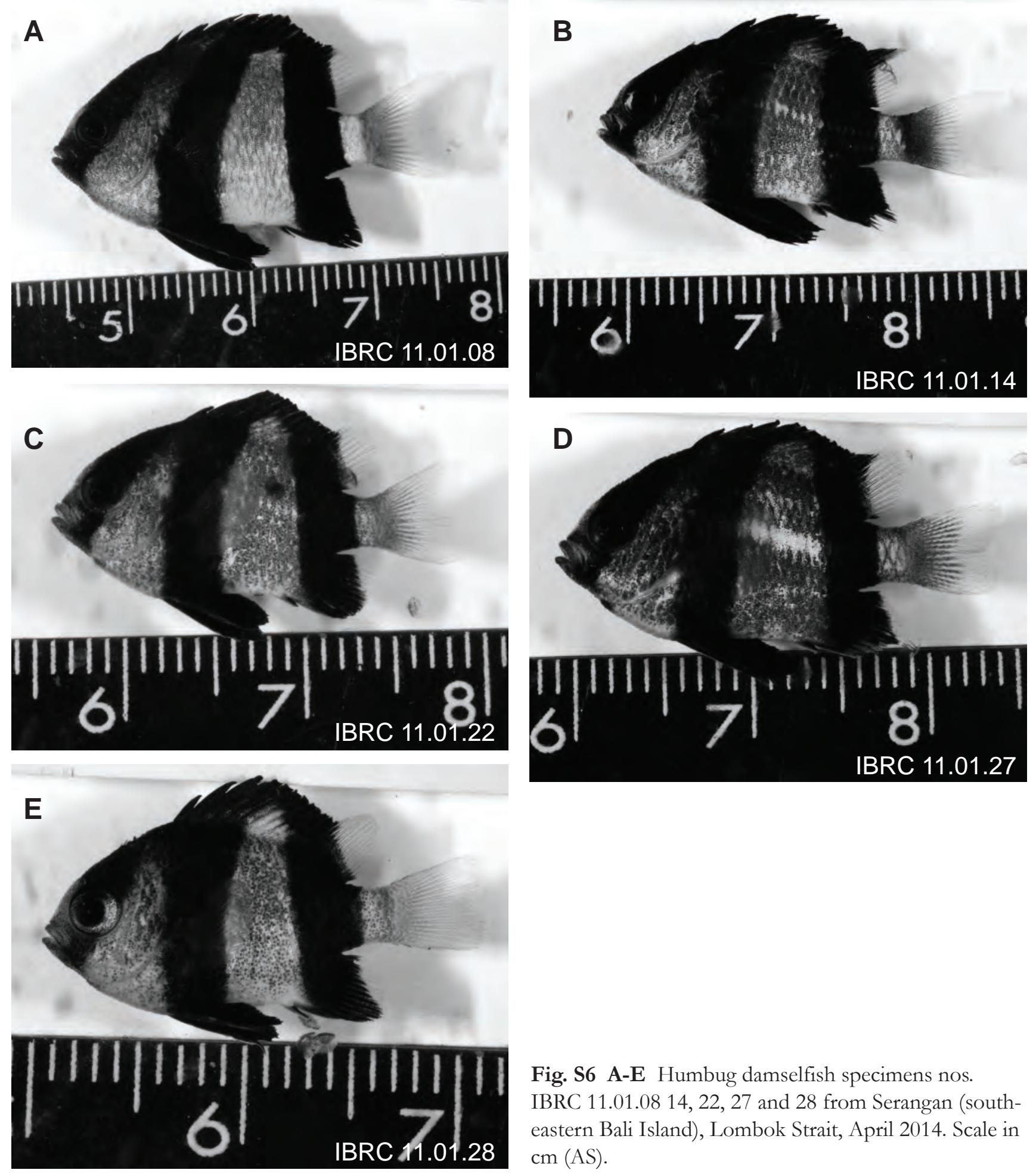

Fig. S6 A-E Humbug damselfish specimens nos. IBRC 11.01.08 14, 22, 27 and 28 from Serangan (southeastern Bali Island), Lombok Strait, April 2014. Scale in $\mathrm{cm}$ (AS). 


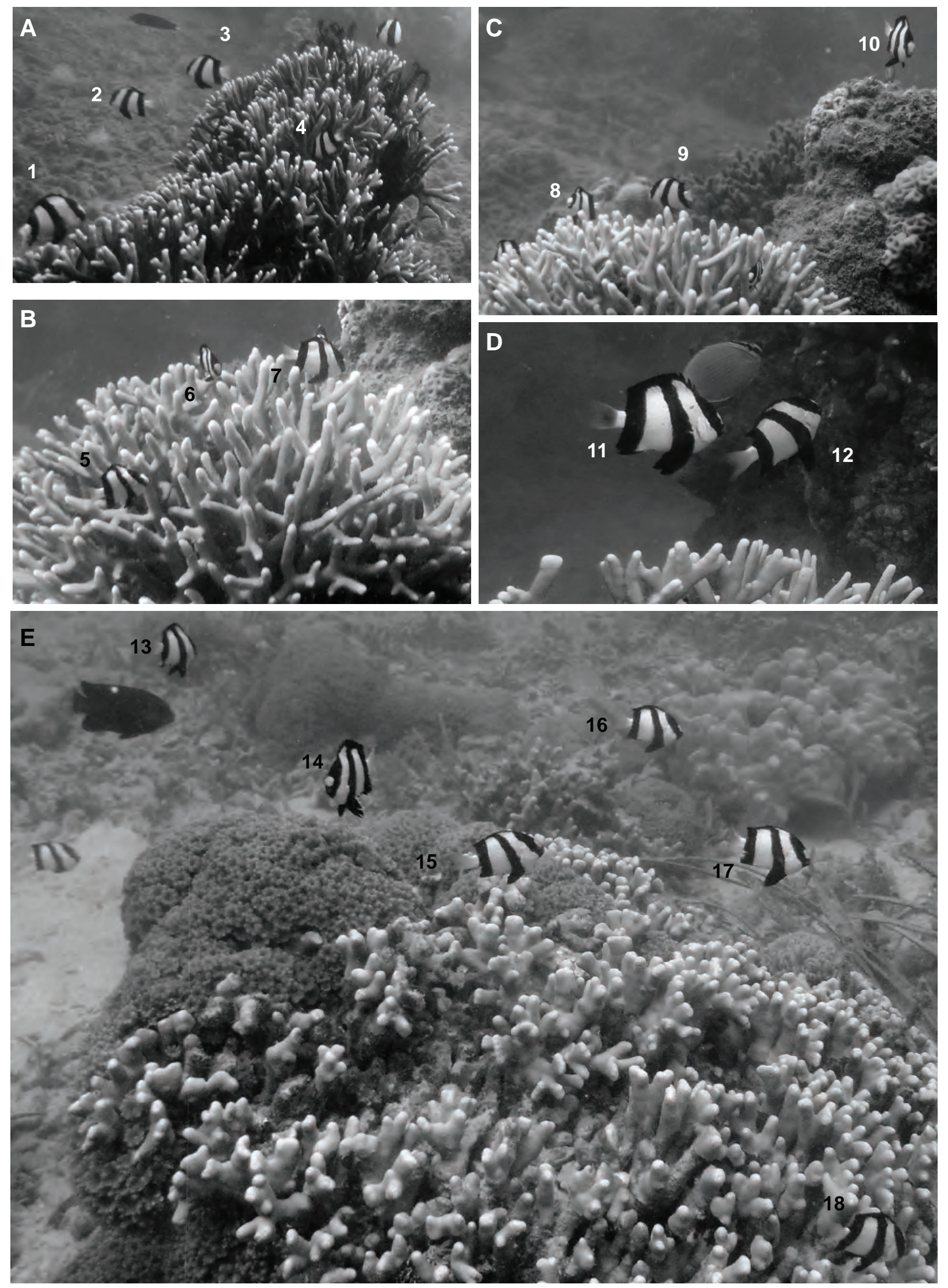

Fig. S7 Humbug damselfish, Dascyllus abudafur and D. aruanus. Individuals nos. Lombok 1-18 examined for pigmentation patterns (PB). A-D Individuals sighted on the fringing reef at the southern tip of Gili Gede (08 46'S 11556'E), 06 August 2014. E Individuals sighted on the reef off southeastern Gili Layar (08 $44^{\circ}$ 'S $\left.115^{\circ} 55^{\prime} \mathrm{E}\right), 07$ August 2014. 